BADAN PENDIDIKAN DAN PELATIHAN KEUANGAN KEMENTERIAN KEUANGAN REPUBLIK INDONESIA
JURNAL BPPK

\title{
KENDALA PENGEMBALIAN ASET HASIL TINDAK PIDANA KORUPSI TRANSNASIONAL
}

\author{
Deddy Candra, Arfin \\ Balai Pendidikan dan Pelatihan Keuangan Pekanbaru, Indonesia Email: deddycan@gmail.com \\ Balai Pendidikan dan Pelatihan Keuangan Pekanbaru, Indonesia Email: arfin.kemenkeu@gmail.com
}

\section{INFO ARTIKEL}

SEJARAH ARTIKEL

Diterima Pertama

27 November 2017

Dinyatakan Dapat Dimuat

\section{KEYWORDS:}

corruption,

strategy,

asset recovery.

\begin{abstract}
ABSTRAK
The eradication of corruption is focused on 3 (three) main issues, namely the prevention, eradication, asset recovery. Finding the actors, proving the criminal activity by law and making sure the sentence is prison have been shown to be not enough to reduce the corruption case effectively, if not accompanied by serious effort to asset recovery. This research aims to analyze: (i) the strategy to prevent and corruption eradication in Indonesia; (ii) the factors that hinder the asset recovery of transnational corruption. This research utilizes the normative legal research and analysis of technical data qualitative. The result shown that the effort to asset recovery is a very difficult process, even on an ideal situation, this process is very complex and involved multi discipline effort, such as legal system differences, bank secrecy, the unwillingness of developed countries to assist asset recovery effort, and weak political will to solve. The UNCAC 2003 have not been fully contemplated into the law of Indonesia, moreover it has not comprehensively and detailedly regulates of asset recovery, thereby implicating the difficulty of asset recovery effectively and efficiently.
\end{abstract}

Pemberantasan korupsi difokuskan pada 3 (tiga) isu pokok, yaitu pencegahan, pemberantasan, dan pengembalian aset hasil korupsi. Mengungkap tindak pidana, menemukan pelakunya, dan menempatkan pelaku pidana di dalam penjara, ternyata belum cukup efektif menekan tingkat kejahatan, jika tidak disertai dengan upaya pengembalian aset. Penelitian ini bertujuan untuk menganalisis: (i) strategi pencegahan dan pemberantasan korupsi di Indonesia; (ii) faktor-faktor yang menjadi kendala dalam pelaksanaan pengembalian aset hasil tindak pidana korupsi yang bersifat transnasional. Penelitian ini menggunakan pendekatan yuridis normatif dan teknis analisis data secara kualitatif. Hasil penelitian menunjukkan bahwa upaya pengembalian aset merupakan suatu proses yang sulit, bahkan dalam keadaan yang ideal sekalipun, upaya pengembalian aset merupakan proses kompleks dan multidisiplin, antara lain perbedaan sistem hukum; sistem kerahasiaan perbankan; ketidaksediaan negara maju untuk membantu upaya pengembalian aset; dan lemahnya kemauan politik. UNCAC Tahun 2003 belum secara memadai berkontemplasi dalam peraturan perundang-undangan di Indonesia, selain itu belum secara komprehensif dan rinci mengatur tentang pengembalian aset hasil tindak pidana korupsi, sehingga mengimplikasikan sulitnya pengembalian aset secara efektif dan efisien.

\section{PENDAHULUAN}

\subsection{Latar Belakang}

Fenomena korupsi tumbuh dan mengakar di berbagai belahan dunia seiring dengan berkembangnya peradaban manusia. Secara harfiah korupsi merupakan sesuatu yang busuk, jahat, dan merusak. Korupsi menimbulkan efek domino yang meluas terhadap eksistensi bangsa dan negara. Korupsi tidak hanya berdampak terhadap satu aspek kehidupan saja, akan tetapi dapat menimbulkan efek domino yang meluas terhadap eksistensi bangsa dan negara, serta memperburuk kondisi ekonomi bangsa (Dikti, 2016:55). Di sejumlah negara berkembang, korupsi telah meresap ke dalam sistem ketatanegaraan (Klitgaard, 1998: xiii). Praktik korupsi terjadi hampir pada semua lapisan birokrasi, baik eksekutif, yudikatif, maupun legislatif, serta telah menjalar ke dunia usaha. Korupsi di Indonesia sudah sampai pada titik nadir yang tidak dapat ditolerir (Mochtar, 2006:103). Gambaran terjadinya praktik korupsi di Indonesia tercermin dalam Indeks Persepsi Korupsi (Corruption Perceptions Index) 2017 yang dirilis oleh Transparency International, menempatkan Indonesia pada urutan 96 dari 180 negara yang diukur, dengan perolehan skor 37 (TI, 2018). Senada dengan itu, Political and Economic Risk Consultancy yang berbasis di Hong Kong dalam laporannya "The Asian Intelligence Report 2017", menempatkan Indonesia menduduki peringkat ketiga negara terkorup setelah Cambodia dan Vietnam (PERC, 2018). Kondisi ini sangat memprihatinkan, terutama 
mengingat bahwa Indonesia dalam survei PERC dari tahun ke tahun tidak pernah beranjak dari posisi-posisi bawah, bahkan dalam survei PERC tahun 2010 Indonesia menempati peringkat pertama sebagai negara terkorup dari 16 (enam belas) negara tujuan investasi di Asia Pasifik, sebagaimana dapat dilihat dalam tabel 1.

Tindak pidana korupsi terjadi secara elitis, endemik, dan sistemik, sehingga tidak hanya merugikan keuangan negara, tetapi juga telah melanggar hak-hak sosial dan ekonomi masyarakat secara luas (Jaya, 2008:57). Kerugian akibat korupsi secara signifikan mengurangi kapasitas negara dalam membangun perekonomian dan menyediakan fasilitas kesejahteraan sosial.

Tindakan korupsi telah menimbulkan kerugian keuangan negara yang sangat signifikan. Indonesia Corruption Watch (ICW, 2016) menyebutkan total kerugian keuangan negara di Indonesia pada tahun 2015 mencapai Rp3,1 triliun, sedangkan kerugian keuangan negara tahun 2016 sebesar Rp.3.085.000.000.000,00 (Tempo, 2017). Data kerugian keuangan negara dalam tindak pidana korupsi berdasarkan pemantauan ICW dapat dilihat dalam grafik 1.

Djaja (2010:28) mengindikasikan bahwa korupsi sudah sangat akut dan menggerogoti seluruh sendi kehidupan berbangsa, sehingga dalam pemberantasannya tidak cukup hanya dengan perluasan perbuatan yang dirumuskan sebagai korupsi dan menggunakan cara-cara konvensional, melainkan diperlukan metode dan cara tertentu, yaitu dengan menetapkan korupsi sebagai kejahatan luar biasa (extra-ordinary crime), sehingga diperlukan penanggulangan yang bersifat luar biasa (extraordinary enforcement) dan tindakan yang luar biasa pula (extra-ordinary measures).

Upaya pemberantasan korupsi (demolishing corruption) melalui upaya pencegahan dan pemberantasannya di Indonesia telah berlangsung sejak tahun 1957 dengan dikeluarkannya Peraturan Penguasa Militer Nomor Prt/PM/06/1957 tanggal 9 April 1957 tentang Pemberantasan Korupsi. Upaya pemerintah dalam menetapkan berbagai produk hukum yang berkaitan dengan pencegahan dan pemberantasan tindak pidana korupsi, diharapkan mampu untuk mengemban fungsi ganda, yaitu sebagai sarana preventif dan sekaligus berfungsi sebagai sarana represif, akan tetapi laju korupsi di Indonesia cenderung meluas dan terus meningkat dari tahun ke tahun.

Upaya pengembalian aset negara yang dicuri (stolen asset recovery) telah menempati posisi penting dalam pemberantasan tindak pidana korupsi, didasarkan pada kenyataan bahwa tindak pidana korupsi telah merampas kekayaan negara yang sangat dibutuhkan untuk merekonstruksi dan merehabilitasi masyarakat melalui pembangunan berkelanjutan (sustainable development). Urgensi pengembalian aset juga tersirat dalam alinea pertama Mukadimah United Nations Convention Against Corruption Tahun 2003.
Sejarah pengembalian aset (asset recovery) hasil tindak pidana korupsi di Indonesia masih belum membuahkan hasil yang signifikan. Aset hasil tindak pidana korupsi yang dilarikan ke luar negeri lebih besar jumlahnya dibandingkan aset hasil tindak pidana korupsi yang berhasil dikembalikan di Indonesia (Listya, 2014:11), sebagaimana tercermin dalam kasus-kasus berikut ini:

1. Adrian Kiki Ariawan selaku Direktur Utama PT Bank Surya.

Berdasarkan Putusan Pengadilan Tinggi DKI Jakarta Nomor 71/PID/2003/PT. DKI tanggal 2 Juni 2003 atas nama Terdakwa Adrian Kiki Ariawan, terbukti secara sah dan meyakinkan telah melakukan tindak pidana korupsi yang mengakibatkan kerugian negara sebesar Rp.1.500.000.000.000,00 (satu koma lima triliun rupiah). Terpidana Adrian Kiki Ariawan mengajukan keberatan pada District Court of Perth di Western Australia, dengan alasan putusan di pengadilan Indonesia dilakukan tanpa hadirnya terdakwa (in absentia) dan pelaksanaan pidana di Lembaga Pemasyarakatan di Indonesia melanggar hak asasi. The High Court of Australia tanggal 18 Desember 2013 memutuskan bahwa keberatan dari Adrian Kiki Ariawan ditolak dan menguatkan penetapan yang dibuat oleh Menteri Kehakiman Australia untuk menyerahkan Adrian ke Indonesia pada tanggal 22 Januari 2014.

2. Djoko Soegiarto Tjandra selaku Direktur PT Era Giat Prima.

Berdasarkan Putusan Mahkamah Agung Republik Indonesia Nomor 12 PK/Pid.Sus/2009 tanggal 11 Juni 2009 atas nama Terdakwa Djoko Soegiarto Tjandra. terbukti secara sah dan meyakinkan telah melakukan tindak pidana korupsi yang mengakibatkan kerugian negara sebesar Rp.904.642.428.369,00 (sembilan ratus empat miliar enam ratus empat puluh dua juta empat ratus dua puluh delapan ribu tiga ratus enam puluh sembilan rupiah). Terpidana kasus korupsi cessie Bank Bali tersebut melarikan diri ke luar negeri sehari sebelum putusan pengadilan. Ekstradisi Djoko S. Tjandra terkendala karena Komite Penasihat Imigrasi dan Kewarganegaraan Papua New Guinea memberikan kewarganegaraan kepada Djoko Tjandra pada tanggal 11 Juni 2012. Kejaksaan menduga Djoko S. Tjandra dilindungi oleh Papua New Guinea karena berdasarkan penelusuran, diketahui Djoko $\mathrm{S}$. Tjandra menanamkan investasi USD 2,000,000, 000 atau sekitar Rp.18.000.000.000.000,00 (delapan belas triliun rupiah) di lahan seluas 100.000 hektar.

3. Hendra Rahardja selaku Komisaris Utama PT Bank Harapan Sentosa.

Berdasarkan Putusan Pengadilan Tinggi DKI Jakarta Nomor 125/Pid/2002/PTDKI tanggal 8 November 2002 atas nama Hendra Rahardja (Terdakwa I), terbukti secara sah dan meyakinkan telah melakukan tindak pidana 
korupsi yang mengakibatkan kerugian negara sebesar Rp2.659.308.000.000,00 (dua triliun enam ratus lima puluh sembilan miliar tiga ratus delapan juta rupiah). Pelaksanaan ekstradisi terganjal karena adanya dugaan perlakuan diskriminatif terhadap etnis Tionghoa di Indonesia sehingga ada kekhawatiran bahwa Hendra Rahardja akan disiksa dan ditekan dalam penyidikan.

4. Hesham Al-Warrag selaku Direktur First Gulf Asia Holdings Limited dan Rafat Ali Rizvi selaku Direktur Pelaksana First Capital Limited.

Berdasarkan Putusan Pengadilan Negeri Jakarta Pusat Nomor 339/PID.B/2010/PN.JKT.PST tanggal 30 November 2010 atas nama Hesham Talaat Mohamed Besheer Al-Warrag (Terdakwa I) dan Rafat Ali Rizvi (Terdakwa II), diadili secara in absentia terbukti secara sah dan meyakinkan bersalah melakukan tindak pidana korupsi dan tindak pidana pencucian uang secara bersamasama yang mengakibatkan kerugian negara sebesar Rp3.115.889.000. 000,00 (tiga triliun seratus lima belas miliar delapan ratus delapan puluh sembilan juta rupiah). Meski masih buron, Hesham dan Rafat mengajukan gugatan ganti rugi kepada Pemerintah Indonesia melalui International Center for the Settlement of Investment Disputes (ICSID) dan Organisasi Kerja Sama Islam (OKI).

Sebagaimana fenomena gunung es (iceberg phenomenon), kasus-kasus korupsi yang diungkapkan di atas, hanya sebagian kecil dari jumlah kasus korupsi yang pernah terjadi di Indonesia. Bagi negara-negara di dunia khususnya negara berkembang di mana grand corruption terjadi, untuk menembus pelbagai permasalahan pengembalian aset yang menyentuh ketentuan-ketentuan hukum negara maju akan terasa teramat sulit, apalagi negara berkembang tersebut tidak memiliki hubungan kerja sama yang baik dengan negara tempat aset curian disimpan. Harta tersebut seakan-akan dilindungi oleh aturan legal procedure negara setempat yang mengaturnya sebagai bagian dari kerahasiaan bank (Zachrie dan Wijayanto, 2010:583).

Upaya pengembalian aset menjadi semakin sulit untuk dilakukan karena alat untuk menyembunyikan (safe haven) hasil tindak pidana korupsi telah melewati batas teritorial suatu negara (transnasional) dan sebagai kejahatan terorganisasi (organized crime), bahkan korupsi seringkali melibatkan korporasi sebagai pelaku. Kasus-kasus penyembunyian aset seringkali melibatkan negara berkembang atau negara miskin sebagai korban yang harta atau kekayaannya dirampas dan kemudian disembunyikan di negaranegara maju, seperti Singapura, Swiss, Hong Kong, Amerika, dan Australia. Data terakhir Global Financial Integrity menyatakan bahwa Indonesia menempati urutan kesembilan untuk aliran dana gelap terbesar di dunia (Kompas, 2016).

Permasalahan pengembalian aset tidaklah sesederhana yang dituliskan (law in books), banyak aspek yang harus diperhatikan dalam menunjang pelaksanaan pengembalian aset hasil tindak pidana korupsi (Syahmin, Elvani, dan Yuningsih, 2013). Kesenjangan antara das sollen dan das sein tersebut telah mengakibatkan pengembalian kerugian negara melalui mekanisme pengembalian aset belum berhasil secara signifikan. Berdasarkan latar belakang masalah tersebut, penelitian secara yang utuh, komprehensif, dan holistik mengenai kompleksitas mekanisme pengembalian aset hasil tindak pidana korupsi, merupakan hal yang sangat penting sebagai bagian dari strategi pencegahan dan pemberantasan tindak pidana korupsi.

Beberapa penelitian terdahulu mempunyai karekteristik yang relatif sama dalam hal tema kajian, meskipun berbeda dalam teori, variabel penelitian, dan metode analisis yang digunakan. Penelitian-penelitian terdahulu menjadi acuan penulis dalam melakukan penelitian ini, sehingga penulis dapat memperkaya teori yang digunakan dalam mengkaji penelitian yang dilakukan. Berikut ini merupakan penelitian terdahulu berupa jurnal, laporan penelitian, dan disertasi, antara lain:

1. Syahmin, Elvani, dan Yuningsih (2013) yang meneliti "Pengembalian Aset Negara Hasil Tipikor Melalui Kerja Sama Timbal Balik Antar Negara”. Hasil penelitian menyimpulkan bahwa pemulihan hasil korupsi mempunyai banyak hambatan karena modus operan di jenis-jenis kasus pidana yang berbeda, dengan memperkuat perangkat hukum dengan teknologi, penyidik, penuntut, dan hakim diharapkan akan semakin lebih efektif dalam memerangi kejahatan internasional yang terorganisir dan korupsi transnasional.

2. Haswandi (2016) yang meneliti "Pengembalian Aset Tindak Pidana Korupsi Pelaku dan Ahli Waris Menurut Sistem Hukum Indonesia". Hasil penelitian menyimpulkan bahwa perangkat hukum tindak pidana korupsi dalam mengembalikan aset hasil korupsi pada saat ini belum sempurna karena hanya mengutamakan uang pengganti terhadap hasil kejahatan korupsi dari pelaku.

3. Prakarsa dan Yulia (2017) yang meneliti "Model Pengembalian Aset (Asset Recovery) Sebagai Alternatif Memulihkan Kerugian Negara dalam Perkara Tindak Pidana Korupsi”. Hasil penelitian menyimpulkan bahwa pengembalian aset kerugian negara lebih dapat diwujudkan melalui jalur hukum perdata, disebabkan dalam proses ini Jaksa Pengacara Negara dapat melakukan gugatan perdata untuk menyelamatkan aset, sekalipun dalam kondisi tidak terbukti unsur tindak pidananya, terdakwa sudah meninggal atau terdakwa sudah divonis bebas.

\subsection{Rumusan Masalah}

Berdasarkan latar belakang masalah di atas, maka masalah penelitian ini dirumuskan, sebagai berikut:

1. Bagamanakah strategi pencegahan dan pemberantasan korupsi di Indonesia? 
2. Apakah faktor-faktor yang menjadi kendala dalam pelaksanaan pengembalian aset hasil tindak pidana korupsi yang bersifat transnasional?

\subsection{Tujuan Penelitian}

Bertumpu pada rumusan permasalahan sebagaimana diuraikan di atas, penelitian ini bertujuan:

1. Untuk menganalisa dan menemukan langkahlangkah strategi pencegahan dan pemberantasan korupsi di Indonesia.

2. Untuk menganalisa faktor-faktor yang menjadi kendala dalam pelaksanaan pengembalian aset hasil tindak pidana korupsi yang bersifat transnasional.

\subsection{Manfaat Penelitian}

Sehubungan dengan tujuan yang dikemukakan di atas, penelitian ini diharapkan dapat memberikan manfaat teoritis dan praktis, sebagai berikut:

1. Manfaat teoritis.

Sebagai sumbangan literatur dan informasi ilmiah untuk memahami dan mendalami tentang penyelesaian masalah pengembalian aset hasil tidak pidana korupsi sebagai bagian integral dari strategi pencegahan dan pemberantasan tindak pidana korupsi di Indonesia.

2. Manfaat praktis.

Sebagai kerangka acuan kepada lembaga pembuat undang-undang dalam mengambil langkah-langkah kebijakan yang tepat dan efisien guna menciptakan suatu konsep yang lebih spesifik dalam pencegahan dan pemberantasan tindak pidana korupsi yang berkaitan dengan pengembalian aset hasil tindak pidana korupsi dalam rangka mengembalikan dan meningkatkan pemasukan keuangan negara.

\section{KERANGKA TEORITIS}

\subsection{Tindak Pidana Korupsi}

Dalam berbagai literatur, korupsi berasal dari kata "corrupteia" dalam bahasa Latin "bribery" atau "seduction". Bribery adalah memberikan atau menyerahkan kepada seseorang agar orang tadi berbuat untuk keuntungan pemberi. Seduction (penggoda) adalah sesuatu yang menarik untuk seseorang berbuat menyeleweng (Anwar dan Adang, 2008).

Centre for Crime Prevention (CICP) sebagai salah satu organ PBB, mendefinisikan korupsi sebagai missus of (public) power for private gain. Korupsi mempunyai dimensi perbuatan yang luas, meliputi tindak pidana suap (bribery); penggelapan (emblezzlement); penipuan (fraud); pemerasan yang berkaitan dengan jabatan (exortion); penyalahgunaan kekuasaan (abuse of power); pemanfaatan kedudukan seseorang dalam aktivitas bisnis untuk kepentingan perorangan yang bersifat illegal (exploiting a conflict interest, insider trading); nepotisme, komisi ilegal yang diterima oleh pejabat publik (illegal commission); dan kontribusi uang secara ilegal untuk partai politik (Suhartoyo, 2014:3-4).

Syed Hussein Alatas, sebagaimana dikutip Kusuma (2001:141), membagi tipologi korupsi menjadi 7 (tujuh) jenis, sebagai berikut:

1. Korupsi transaktif (transactive corruption) adalah korupsi yang menunjukkan adanya kesepakatan timbal-balik antara pihak pemberi dan pihak penerima demi keuntungan kedua belah pihak dan dengan aktif diusahakan tercapainya keuntungan itu oleh kedua belah pihak.

2. Korupsi memeras (extortive corruption) adalah jenis korupsi dengan keadaan pihak pemberi dipaksa untuk menyuap guna mencegah kerugian yang sedang mengancam dirinya, kepentingannya atau orang lain, dan hal-hal yang dihargainya.

3. Korupsi investif (investive corruption) adalah pemberian barang atau jasa tanpa ada pertalian langsung dengan keuntungan tertentu selain keuntungan yang dibayangkan akan diperoleh di masa yang akan datang.

4. Korupsi perkerabatan (nepotistic corruption) adalah penunjukan yang tidak sah terhadap teman atau sanak saudara untuk memegang jabatan dalam pemerintahan atau tindakan yang memberikan perlakuan yang mengutamakan dalam bentuk uang atau bentuk-bentuk lain kepada mereka secara bertentangan dengan norma dan peraturan yang berlaku.

5. Korupsi defensif (defensive corruption) adalah perilaku korban korupsi dengan pemerasan sebagai bentuk mempertahankan diri.

6. Korupsi otogenik (autogenic corruption) adalah korupsi yang tidak melibatkan orang lain dan pelakunya hanya seorang.

7. Korupsi dukungan (suportive corruption) adalah korupsi yang tidak secara langsung menyangkut uang atau imbalan langsung dalam bentuk lain. Tindakan-tindakan yang dilakukan adalah untuk melindungi dan memperkuat korupsi yang sudah ada.

Undang-Undang Nomor 20 Tahun 2001 tentang Perubahan Atas Undang-Undang Nomor 31 Tahun 1999 tentang Pemberantasan Tindak Pidana Korupsi, mendefinisikan 30 (tiga puluh) bentuk tindak pidana korupsi beserta sanksinya. Tiga puluh bentuk tindak pidana korupsi ini terbagi menjadi 7 (tujuh) kelompok, yaitu kerugian keuangan negara; suap menyuap; penggelapan dalam jabatan; pemerasan; perbuatan curang; benturan kepentingan dalam pengadaan barang; dan menerima grafitikasi, sebagaimana dapat dilihat dalam tabel 2 .

Terdapat beberapa teori yang menjelaskan faktor-faktor penyebab dilakukannya tindak pidana korupsi, yaitu:

1. Triangle Fraud Theory.

Donald Cressey (1953) mencetuskan konsep segitiga kecurangan (fraud triangle) sebagai suatu ilustrasi yang menggambarkan faktor risiko kecurangan yang terjadi. 
Gambar 1. Segitiga Kecurangan

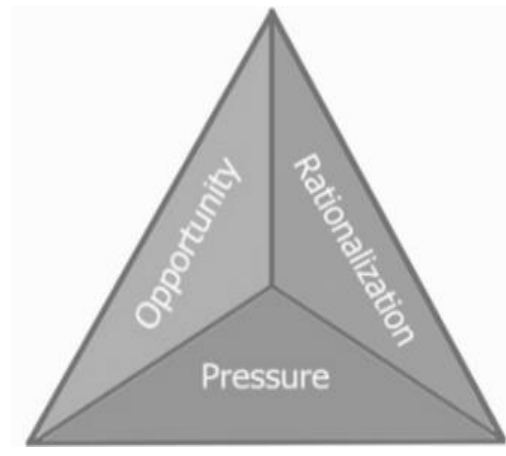

Sumber: (Suradi, 2006:8).

Fraud triangle menjelaskan 3 (tiga) faktor yang hadir dalam setiap situasi fraud, sebagai berikut:

a. Pressure (tekanan), yaitu adanya insentif/ tekanan/kebutuhan untuk melakukan fraud. Tekanan dapat mencakup hampir semua hal, termasuk gaya hidup, tuntutan ekonomi, keuangan, dan nonkeuangan.

b. Opportunity (kesempatan), yaitu situasi yang membuka kesempatan untuk memungkinkan suatu kecurangan terjadi, disebabkan pengendalian internal perusahaan yang lemah, kurangnya pengawasan dan penyalahgunaan wewenang. Di antara elemen fraud diamond yang lain, opportunity merupakan elemen yang paling memungkinkan diminimalisir melalui penerapan proses, prosedur, dan upaya deteksi dini terhadap fraud.

c. Rationalization (rasionalisasi), yaitu adanya sikap, karakter, atau serangkaian nilai-nilai etis yang memperbolehkan pihak-pihak tertentu untuk melakukan tindakan kecurangan, atau orang-orang yang berada dalam lingkungan yang cukup menekan yang membuat mereka merasionalisasi tindakan fraud. Rasionalisasi atau sikap (attitude) yang paling banyak digunakan adalah hanya meminjam (borrowing) aset yang dicuri dan alasan bahwa tindakannya untuk membahagiakan orang-orang yang dicintainya

Teori ini kemudian dikembangkan secara skematis oleh Association of Certified Fraud Examiners (ACFE), yang menggambarkan fraud dalam bentuk fraud tree, yang mempunyai 3 (tiga) cabang utama, yaitu korupsi (corruption), penggelapan aset (asset missapropriation), dan pernyataan yang salah (fraudulent missatement).

2. GONE Theory.

Menurut Jack Bologne, sebagaimana dikutip (Ayu dan Chariri, 2015:4) bahwa akar penyebab korupsi sebagai berikut:

a. Greeds (keserakahan), berkaitan dengan adanya perilaku serakah yang secara potensial ada di dalam diri setiap orang.

b. Opportunities (kesempatan), berkaitan dengan keadaan organisasi atau instansi atau masyarakat yang sedemikian rupa, sehingga terbuka kesempatan bagi seseorang untuk melakukan korupsi.

c. Needs (kebutuhan), berkaitan dengan faktorfaktor yang dibutuhkan oleh individu-individu untuk menunjang hidupnya yang wajar.

d. Exposures (pengungkapan), berkaitan dengan tindakan atau konsekuensi yang dihadapi oleh pelaku kecurangan apabila pelaku diketemukan melakukan kecurangan.

3. Hierarchy of Needs Theory.

Abraham Maslow menyusun teori motivasi manusia, yang memandang variasi kebutuhan manusia tersusun dalam bentuk hierarki atau berjenjang. Setiap jenjang kebutuhan dapat dipenuhi hanya jenjang sebelumnya telah (relatif) terpuaskan.

Gambar 2. Hierarki Kebutuhan Maslow

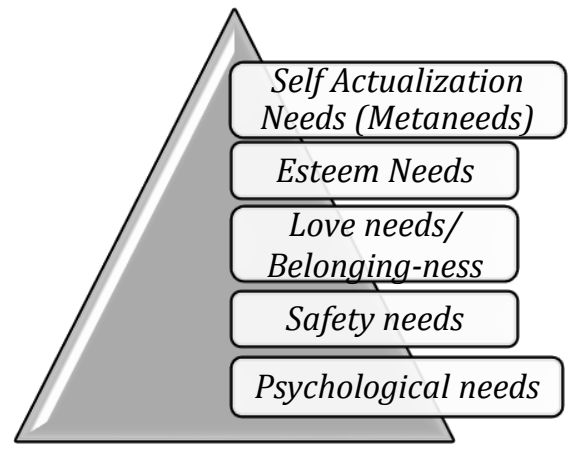

Sumber: Sunyoto $(2013,2-3)$.

Maslow menerangkan 5 (lima) tingkatan kebutuhan dasar manusia, sebagai berikut:

a. Basic needs atau psychological needs, merupakan kebutuhan yang paling penting, seperti kebutuhan akan makanan. Dominasi kebutuhan fisiologi ini relatif lebih tinggi dibanding dengan kebutuhan lain dan menimbulkan kebutuhan-kebutuhan lain.

b. Safety needs (kebutuhan akan keselamatan), meliputi keamanan, kemantapan, ketergantungan, kebebasan dari rasa takut, cemas, dan kekalutan; kebutuhan akan struktur, ketertiban, hukum, batas-batas kekuatan pada diri, pelindung, dan sebagainya.

c. Love needs (kebutuhan rasa memiliki dan rasa cinta), merupakan kebutuhan yang muncul setelah kebutuhan fisiologis dan kebutuhan keselamatan telah terpenuhi.

d. Esteem needs (kebutuhan akan harga diri), terbagi dalam 2 (dua) peringkat, yaitu:

1) Keinginan akan kekuatan, akan prestasi, berkecukupan, unggul, kemampuan, percaya diri, kemerdekaan, dan kebebasan.

2) Hasrat akan nama baik atau gengsi dan harga diri, prestise (penghormatan dan penghargaan dari orang lain), status, ketenaran. kemuliaan, dominasi, pengakuan, perhatian, dan martabat. 
e. Self actualization needs (kebutuhan akan perwujudan diri), yaitu kecenderungan untuk mewujudkan dirinya sesuai dengan kemampuannya.

4. Ramirez Torres Theory.

Menurut Torres, sebagaima dikutip Indawati (2016:17) suatu tindak korupsi akan terjadi jika memenuhi persamaan berikut:

$\mathrm{Rc}>$ Pty $\mathrm{x}$ Prob
$\mathrm{Rc}=$ Reward
Pty $=$ Penalty
Prob $=$ Probability

Korupsi adalah kejahatan kalkulasi atau perhitungan (crime of calculation) bukan hanya sekedar keinginan (passion). Seseorang akan melakukan korupsi jika hasil $(\mathrm{Rc}=$ Reward $)$ yang didapat dari korupsi lebih tinggi dari hukuman (Pty = Penalty $)$ yang didapat dengan kemungkinan (Prob = Probability) tertangkapnya yang kecil.

5. Vroom Theory.

Menurut teori Vroom, terdapat hubungan antara kinerja seseorang dengan kemampuan dan motivasi yang dimiliki sebagaimana tertulis dalam fungsi, sebagai berikut:

$\mathrm{P}=\mathrm{f}(\mathrm{A}, \mathrm{M})$

$\mathrm{P}=$ Performance

$\mathrm{A}=$ Ability

$\mathrm{M}=$ Motivation

Kinerja (performance) seseorang merupakan fungsi dari kemampuannya (ability) dan motivasi (motivation). Kemampuan seseorang ditunjukkan dengan tingkat keahlian (skill) dan tingkat pendidikan (knowledge) yang dimilikinya. Tingkat motivasi dengan skill dan knowledge yang lebih tinggi akan menghasilkan kinerja yang lebih baik, dengan asumsi variabel M (motivation) adalah tetap. Vroom merumuskan fungsi tentang motivasi, sebagai berikut:

$\mathrm{M}=\mathrm{f}(\mathrm{E}, \mathrm{V})$

$\mathrm{M}=$ Motivation

$\mathrm{E}=$ Expectation

$\mathrm{V}=$ Valance $/$ Value

Motivasi seseorang akan dipengaruhi oleh harapan (expectation) orang yang bersangkutan dan nilai (value) yang terkandung dalam setiap pribadi seseorang (Waluyo, 2014:174-175).

6. Klitgaard Theory.

Teori Klitgaard memformulasikan terjadinya tindak pidana korupsi dengan rumusan model matematis, sebagai berikut:

$$
\mathbf{C}=\mathbf{M}+\mathbf{D}-\mathbf{A}
$$

Keterangan:

$\mathrm{C}=$ Corruption

$\mathrm{M}=$ Monopoly of Power

$\mathrm{D}=$ Discretion by Official

$\mathrm{A}=$ Accountability

Menurut Klitgaard, monopoli kekuatan oleh pimpinan (monopoly of power) ditambah dengan besarnya kekuasaan yang dimiliki (discretion of official) tanpa adanya pengawasan yang memadai (minus accountability), menyebabkan dorongan melakukan tindak pidana korupsi. Tindak pidana korupsi terjadi karena adanya monopoli atas kekuasaan dan diskresi (hak untuk melakukan penyimpangan pada suatu kebijakan), tetapi dalam kondisi tidak adanya akuntabilitas (Rohim, 2008:2).

Rumusan korupsi tersebut memiliki persamaan dengan ungkapan Lord Acton, "Power tends to corrupt, and absolute power corrupts absolutely", bahwa kekuasaan cenderung untuk korupsi dan kekuasaan yang absolut cenderung korupsi absolut (Djaja, 2010:28), namun hukum tanpa kekuasaan adalah angan-angan, sedangkan kekuasaan tanpa hukum adalah anarki (Atmasasmita, 2016:102).

Setiap kekuasaan selalu mengandung potensi disalahgunakan (misbruik van recht) atau dilaksanakan sewenang-wenang (arbitraty willekeur) atau dilaksanakan dengan melampaui wewenang (detournent de pouvoir), disebabkan sebagai berikut:

1. Kekuasaan mengandung hak dan wewenang (recht en bevoegdheid).

2. Hak dan wewenang memberikan posisi lebih jika dibandingkan dengan subyek yang dituntut atau pencari keadilan (Manan, 2006:4).

Meluasnya praktik korupsi tidak hanya mengandung aspek ekonomis (merugikan keuangan/perekonomian negara dan memperkaya diri sendiri/orang lain), tetapi juga korupsi jabatan, korupsi kekuasaan, korupsi politik, korupsi nilai-nilai demokrasi, korupsi moral, dan sebagainya. Tindak pidana korupsi membawa dampak yang luar biasa terhadap kuantitas dan kualitas tindak pidana lainnya, hal ini disebabkan semakin besarnya jurang perbedaan antara si kaya dan si miskin telah memicu meningkatnya jumlah dan modus kejahatan yang terjadi di masyarakat (Supandji, 2009:1).

Menurut Suseno, sebagaimana dikutip Soemodihardjo (2008:3) mengungkapkan bahwa praktik korupsi di Indonesia telah sampai pada yang paling membahayakan dalam kehidupan berbangsa dan bernegara. Pendapat Suseno tersebut tentu didasari oleh kondisi perekonomian negara selalu berada dalam posisi yang kurang baik bagi perjalanan pembangunan di Indonesia, tetapi dalam perjalanannya kemudian lebih dari itu, yaitu membahayakan dan merusak perekonomian masyarakat.

Korupsi memberikan pengaruh secara langsung terhadap tingkat pertumbuhan ekonomi baik itu positif maupun negatif. Di kalangan ahli ekonomi memperdebatkan dampak korupsi terhadap perekonomian. Perdebatan yang dimaksud mengenai Grease the Wheels Hypothesis dan Sand the Wheels Hypothesis, sebagai berikut:

1. Grease the Wheels Hypothesis (GWH) merupakan sebuah hipotesis mengenai bagaimana korupsi dapat memberikan pengaruh yang menguntungkan pada sebuah negara ketika aspek 
lembaga pemerintahnya tidak bekerja efektif. Konsep pemikiran GWH memiliki filosofi menarik bahwa korupsi dapat memberikan keuntungan dengan menghilangkan distorsi yang diakibatkan oleh lembaga yang tidak berjalan baik. Korupsi dapat menjadi pelumas (grease) untuk mempersingkat proses terjadinya kegiatan ekonomi. GWH sebagai mesin untuk menghindari masalah birokratis yang dapat meningkatkan efisiensi dari investasi dan juga pertumbuhan ekonomi (Wiennata, 2014:69). Pendukung SWH, antara lain Leff (1964), Huntington (1968), Lui (1985), Egger dan Winner (2005), Meon dan Weill (2006), dan Gazda (2010). Hasil penelitian Lui (1985:760) menunjukkan bahwa korupsi mampu mempercepat proses birokrasi dan meminimisasi biaya tunggu. Senada dengan itu, Dreher dan Gassebner (2013:413) menunjukkan bahwa korupsi dapat menfasilitasi masuknya perusahaan terhadap pasar dalam tingkat regulasi yang tinggi. Houston (2007:335) dalam penelitiannya mengembangkan model ekonomi yang mendukung GHW dan menemukan 12 (dua belas) negara di mana efek positif korupsi pada ekonomi lebih besar dari efek negatif yang ditimbulkan yang ditunjukkan dengan ratio of expansionary to restrictive corruption di atas satu. Dua belas negara tersebut adalah Haiti, Bangladesh, both Congos, Chad, Venezuela, Côte d'Ivoire, Pakistan, Burundi, Paraguay, Nigeria, dan Georgia, yang merupakan negara miskin dengan kondisi birokrasi yang buruk, tingkat kepercayaan yang rendah terhadap pemerintah, dan kerangka hukum yang lemah. Republik Rakyat Tiongkok menjadi salah satu contoh negara yang menikmati dampak positif dari korupsi sebagaimana yang dijelaskan dalam GHW. Proses penggalian barang tambang dan penjualan di luar rencana yang sudah ditetapkan di dalam aturan telah memperluas jangkauan kegiatan ekonomi Tiongkok pada saat itu. Korupsi telah mendorong pertumbuhan ekonomi yang cepat dan menimbulkan diversifikasi ekonomi. Menurut Pradiptyo (2016:9), kelemahan mendasar hipotesis GWH terletak pada beberapa hal, yaitu:

a. Dampak korupsi diasumsikan hanya terbatas pada bidang ekonomi.

b. Kelancaran birokrasi akibat korupsi hanya menguntungkan individu atau kelompok berpenghasilan menengah ke atas, sementara individu atau kelompok berpenghasilan menengah ke bawah akan menjadi korban dari sistem tersebut.

2. Sand the Wheels Hypothesis (SWH) merupakan sebuah hipotesis mengenai bagaimana korupsi berdampak negatif terhadap pertumbuhan ekonomi. Filosofi yang terkandung dalam SWH adalah ibarat pasir yang saat berjalan menggunakan kendaraan bermotor di atasnya, akan terasa lambat atau bahkan selip tidak bisa melaju. Pendukung SWH, antara lain RoseAckerman (1978), Shleifer dan Vishny (1993), Tanzi (1998), Aufmann dan Wei (1999), Bowles 2000), Wei (2000), Jain (2001), Mo (2001), Mauro (1995, 1998), Meon dan Sekkat (2005), Henderson dan Kuncoro (2006), Rivayani (2008), dan Chang (2013). Hasil penelitian Mauro (1995, 1998), menunjukkan bahwa korupsi berhubungan negatif dengan pertumbuhan ekonomi dan merusak investasi yang ada, artinya jika korupsi meningkat maka investasi domestik akan terganggu dan pertumbuhan ekonomi akan mengalami penurunan (Nawatmi, 2016:15). Penelitian Treisman (2000:399-457) menemukan bukti bahwa ada hubungan terbalik antara korupsi dan pertumbuhan ekonomi, semakin tinggi korupsi di suatu negara, semakin rendah kinerja ekonomi negara itu.

Dampak korupsi terhadap pembangunan dapat diukur dengan berbagai indikator. Sebagai contoh, indeks persepsi korupsi (corruption perception index) yang diterbitkan oleh Transparency International yang membandingkan suatu negara dengan sejumlah indikator ekonomi, seperti tingkat pendapatan per kapita (produk domestik bruto), kesenjangan kemiskinan (poverty gap), investasi (foreign direct investment), dan tingkat pengangguran (Kompas, 2015), sebagaimana dapat dilihat pada tabel 3 yang menunjukkan adanya korupsi berkorelasi negatif signifikan 1\% dengan pertumbuhan ekonomi, artinya semakin tinggi korupsi, maka semakin rendah tingkat pertumbuhan ekonomi di Indonesia pada derajat kesalahan (alpha) sebesar 1\%. Tabel 3 juga menunjukkan adanya korelasi negatif signifikan 1\% antara korupsi dan pendapatan per kapita, serta pembelanjaaan kesehatan publik, artinya semakin tinggi tingkat korupsi di Indonesia, maka pendapatan per kapita menjadi semakin rendah dan pembelanjaan kesehatan publik juga semakin rendah. Korelasi korupsi dengan kemiskinan adalah positif signifikan. Hal ini menunjukkan bahwa semakin tinggi korupsi di Indonesia, maka semakin tinggi tingkat kemiskinan dan kesenjangan kemiskinan di Indonesia (Pradiptyo, 2016:34). Temuan ini sesuai dengan penelitian RoseAckerman (1978), Shleifer dan Vishny (1993), Bardhan (1997), Mauro (1995, 1998), Bowles (2000), Jain (2001), Mo (2001), Gupta dan Alonso-Terme (2002), Meon dan Sekkat (2005), Cuervo-Cazzura (2006), dan Dzhumashev (2014), yang menyatakan bahwa korupsi berdampak negatif terhadap pertumbuhan ekonomi.

Pada tahun 1981, Indonesia mencapai pertumbuhan ekonomi tertinggi sepanjang sejarah, dengan persentase sebesar 9,90\%. Pertumbuhan ekonomi relatif tinggi juga terjadi tahun 1995, yaitu sebesar 8,40\%, namun di tengah gencarnya Gerakan Nasional Pemberantasan Korupsi berdasarkan Instruksi Presiden Nomor 5 Tahun 2004 tentang Percepatan Pemberantasan Korupsi, pertumbuhan ekonomi di Indonesia sejak tahun 2004-2016 hanya berkisar 4,90\%-6,81\% (BPS, 2017). Kendati demikian, berdasarkan hasil penelitian Henderson dan Kuncoro 
tidak menemukan bukti yang mendukung hipotesis bahwa GWH terjadi di Indonesia (Henderson dan Kuncoro, 2006). Dengan demikian, dampak korupsi khususnya di Indonesia adalah menghambat pertumbuhan ekonomi dan merugikan perekonomian nasional.

\subsection{Pengembalian Aset}

Dalam dunia internasional, istilah pengembalian aset tidak mempunyai definisi yang baku. Fleming (2005:1) mendefinisikan pengembalian aset sebagai proses pelaku-pelaku kejahatan dicabut, dirampas, dan dihilangkan haknya dari hasil tindak pidana dan/atau dari sari sarana tindak pidana.

Yanuar (2007:104) mendefinisikan pengembalian aset sebagai sistem penegakan hukum yang dilakukan oleh negara korban tindak pidana korupsi untuk mencabut, merampas, dan menghilangkan hak atas aset hasil tindak pidana korupsi dari pelaku tindak pidana korupsi melalui rangkaian proses dan mekanisme, baik secara pidana atau perdata, aset hasil tindak pidana korupsi, baik yang ada di dalam maupun di luar negeri, dilacak, dibekukan, dirampas, disita, diserahkan, dan dikembalikan kepada negara korban tindak pidana korupsi, sehingga dapat mengembalikan kerugian keuangan negara yang diakibatkan oleh tindak pidana korupsi dan untuk mencegah pelaku tindak pidana korupsi menggunakan aset hasil tindak pidana korupsi sebagai alat atau sarana untuk melakukan tindak pidana lainnya, serta memberikan efek jera bagi pelaku dan/atau calon pelaku tindak pidana korupsi.

Pengembalian aset korupsi merupakan sistem penegakan hukum yang menghendaki adanya suatu proses peniadaan hak atas aset pelaku dari negara korban dengan cara meniadakan hak atas aset pelaku secara perdata maupun pidana, dilakukan dengan cara penyitaan, pembekuan, perampasan, baik dalam kompetensi lokal, regional, maupun internasional, sehingga kekayaan dapat dikembalikan kembali kepada negara korban yang sah (Adji, 2009: 149-150).

Dari rumusan pengertian di atas, terdapat beberapa unsur penting dalam pengembalian aset hasil tindak pidana korupsi, yaitu:

1. Pengembalian aset merupakan sistem penegakan hukum.

2. Penegakan hukum tersebut dilakukan baik melalui jalur pidana maupun jalur perdata.

3. Melalui kedua jalur tersebut, aset hasil tindak pidana korupsi dilacak, dibekukan, dirampas, disita, diserahkan, dan dikembalikan kepada negara korban tindak pidana korupsi.

4. Pelacakan, pembekuan, perampasan, penyitaan, penyerahan, dan pengembalian dilakukan terhadap aset hasil tindak pidana korupsi baik yang ditempatkan di dalam maupun di luar negeri.

5. Sistem penegakan hukum dilakukan oleh negara korban tindak pidana korupsi yang dilaksanakan oleh institusi penegak hukum.
6. Sistem ini memiliki tujuan-tujuan sebagai berikut:

a. Mengembalikan kerugian negara korban tindak pidana korupsi yang ditimbulkan oleh pelaku tindak pidana korupsi;

b. Mencegah penggunaan atau pemanfaatan aset-aset tersebut sebagai alat atau sarana oleh pelaku tindak pidana korupsi untuk melakukan tindak pidana lainnya;

c. Memberikan efek jera bagi pihak lain yang beriktikad melakukan tindak pidana korupsi Yanuar (2007:104-105).

Dalam sejarah perkembangan peraturan perundang-undangan tentang pemberantasan tindak pidana korupsi, terdapat beberapa ketentuan mengenai pengembalian dan mekanisme pengembalian kerugian keuangan negara, sebagai berikut:

1. Peraturan Penguasa Militer Nomor Prt/PM/08/1957 tanggal 27 Mei 1957 tentang Penilikan Terhadap Harta Benda.

2. Peraturan Penguasa Militer Nomor Prt/PM/011/1957 tanggal 1 Juli 1971 tentang Penyitaan dan Perampasan Barang-Barang.

3. Peraturan Penguasa Perang Pusat Angkatan Darat Nomor Prt/Peperpu/013/1958 tanggal 16 April 1958 tentang Pengusutan, Penuntutan, Pemeriksaan Perbuatan Korupsi Pidana, dan Penilikan Harta Benda.

4. Peraturan Penguasa Perang Pusat Kepala Staf Angkatan Laut Nomor Prt/Z.I./I/7 tanggal 17 April 1958 tentang Pengusutan, Penuntutan, Pemeriksaan Perbuatan Korupsi Pidana, dan Penilikan Harta Benda.

5. Peraturan Pemerintah Nomor 43 Tahun 1948 tentang Mengadakan Perubahan dalam Peraturan Pemerintah Nomor 11 Tahun 1947 dari Hal Barang-Barang yang Dirampas atas Kekuatan Keputusan Pengadilan, serta Barang-barang Bukti yang Tidak Diambil Oleh yang Berhak.

6. Peraturan Pemerintah Pengganti Undang-Undang Nomor 24 Tahun 1960 tentang Pengusutan, Penuntutan, dan Pemeriksaan Tindak Pidana Korupsi (Lembaran Negara Tahun 1960 Nomor 72 dan Tambahan Lembaran Negara Nomor 2011)

7. Undang-Undang Nomor 20 Tahun 2001 tentang Perubahan atas Undang-Undang Nomor 31 Tahun 1999 tentang Pemberantasan Tindak Pidana Korupsi (Lembaran Negara Tahun 2001 Nomor 134 dan Tambahan Lembaran Negara Nomor 4150).

Dua belas tahun lamanya Indonesia telah meratifikasi United Nations Convention Against Corruption, yaitu dengan diundangkannya UndangUndang Nomor 7 Tahun 2006 tentang Pengesahan United Nations Convention Against Corruption, 2003 (Konvensi Perserikatan Bangsa-Bangsa Anti Korupsi, 2003) pada tanggal 18 April 2006, namun hasil kajian analisis kesenjangan (gap analysis study), menunjukkan bahwa sejumlah penyesuaian perlu 
segera dilakukan untuk memenuhi klausul-klausul di dalam UNCAC Tahun 2003, khususnya bidang kriminalisasi dan peraturan perundang-undangan. Indonesia menjadi salah satu negara pertama yang dikaji oleh negara peserta lainnya di dalam skema UNCAC Tahun 2003 (Stranas PPK, 2015).

Pasal 32, Pasal 33, Pasal 34, dan Pasal 38 Undang-Undang Nomor 20 Tahun 2001 tentang Perubahan atas Undang-Undang Nomor 31 Tahun 1999 tentang Pemberantasan Tindak Pidana Korupsi mengatur pengembalian aset hasil tindak pidana korupsi, memberikan dasar hukum bagi negara yang dipresentasikan oleh Jaksa Pengacara Negara atau pihak instansi yang dirugikan untuk melakukan gugatan perdata terhadap pelaku tindak pidana korupsi atau ahli warisnya. Kebijakan formulasi dalam hukum nasional yang selaras dan yang tidak selaras dengan pengaturan mengenai tindak pidana korupsi dalam UNCAC Tahun 2003, dapat dilihat dalam tabel 4 .

Hingga saat ini, pemerintah belum membentuk suatu peraturan pelaksana terhadap keberlakuan UNCAC di Indonesia. Undang-Undang Nomor 20 Tahun 2001 tentang Perubahan atas Undang-Undang Nomor 31 Tahun 1999 tentang Pemberantasan Tindak Pidana Korupsi belum secara komprehensif dan rinci mengatur tentang pengembalian aset hasil tindak pidana korupsi.

Menurut penulis, merupakan suatu kekeliruan jika para ahli hukum berpendapat bahwa UNCAC Tahun 2003 serta merta berlaku, memiliki kekuatan hukum mengikat, dan dapat diterapkan dalam perkara korupsi di Indonesia dengan alasan telah diratifikasi. UndangUndang Nomor 7 Tahun 2006 hanya bersifat pengesahan terhadap UNCAC Tahun 2003, bukan bersifat pemberlakuan ketentuan suatu tindak pidana, disebabkan sistem hukum pidana di Indonesia mengakui asas legalitas sebagaimana termuat dalam Pasal 1 ayat (1) KUHP, yang menentukan bahwa suatu perbuatan tidak dapat dipidana, kecuali berdasarkan kekuatan ketentuan perundang-undangan pidana yang telah ada (nullum delictum noella poena sine praevia lege poenali).

\section{METODE PENELITIAN}

\subsection{Pendekatan dan Jenis Penelitian}

Penelitian ini menggunakan pendekatan yuridis normatif (normative legal research). Menurut Soekanto dan Mamudji (2001:13) pendekatan yuridis normatif adalah penelitian hukum yang dilakukan dengan cara meneliti bahan pustaka atau data sekunder sebagai bahan dasar untuk diteliti dengan cara mengadakan penelusuran terhadap peraturan-peraturan dan literatur-literatur yang berkaitan dengan permasalahan yang diteliti. Dalam penelitian ini, pendekatan yuridis normatif digunakan untuk mengkaji dan menganalisis asas-asas hukum, hukum in abstracto, in konkreto, sinkronisasi vertical, dan horizontal hukum, serta merumuskan kaidah-kaidah hukum yang berkaitan dengan pencegahan dan pemberantasan tindak pidana korupsi, sehubungan dengan pengembalian aset hasil tindak pidana korupsi.
Dalam menganalisis hasil penelitian, penulis menggunakan kualitatif yang bersifat deskriptif untuk menggambarkan perubahan-perubahan kebijakan hukum di Indonesia, dengan cara menggali, mengungkap, dan mendeskripsikan pengembalian aset tindak pidana korupsi.

\subsection{Sumber Data}

Penelitian hukum normatif menggunakan data sekunder sebagai sumber data utamanya, berbeda dengan penelitian hukum empiris yang sumber data utamanya adalah data primer. Dalam penelitian ini, sumber data diperoleh melalui penelitian kepustakaan (library research). Adapun sumber data sekunder dalam penelitian hukum normatif terbagi menjadi 3 (tiga) bahan hukum, yaitu:

1. Bahan hukum primer.

Penelitian ini menelaah dan menganalisa makna yang terkandung dalam berbagai ketentuan peraturan perundang-undangan, yaitu:

a. Undang-Undang Dasar Negara Republik Indonesia Tahun 1945.

b. Undang-Undang Nomor 1 Tahun 1979 tentang Ekstradisi (Lembaran Negara Tahun 1979 Nomor 2 dan Tambahan Lembaran Negara Nomor 3130).

c. Undang-Undang Nomor 11 Tahun 1980 tentang Tindak Pidana Suap (Lembaran Negara Tahun 1980 Nomor 58 dan Tambahan Lembaran Negara Nomor 3178).

d. Undang-Undang Nomor 8 Tahun 1981 tentang Hukum Acara Pidana (Lembaran Negara Tahun 1981 Nomor 76 dan Tambahan Lembaran Negara Nomor 3258).

e. Undang-Undang Nomor 28 Tahun 1999 tentang Penyelenggaraan Negara Yang Bersih Dan Bebas Dari Korupsi, Kolusi, Dan Nepotisme (Lembaran Negara Tahun 1999 Nomor 75 dan Tambahan Lembaran Negara Nomor 3851).

f. Undang-Undang Nomor 20 Tahun 2001 tentang Perubahan Atas Undang-Undang Nomor 31 Tahun 1999 tentang Pemberantasan Tindak Pidana Korupsi (Lembaran Negara Tahun 2001 Nomor 134 dan Tambahan Lembaran Negara Nomor 4150).

g. Undang-Undang Nomor 2 Tahun 2002 tentang Kepolisian Negara Republik Indonesia (Lembaran Negara Tahun 2002 Nomor 2 dan Tambahan Lembaran Negara Nomor 4168).

h. Undang-Undang Nomor 30 Tahun 2002 tentang Komisi Pemberantasan Tindak Pidana Korupsi (Lembaran Negara Tahun 2002 Nomor 137 dan Tambahan Lembaran Negara Nomor 4250).

i. Undang-Undang Nomor 17 Tahun 2003 tentang Keuangan Negara (Lembaran Negara Tahun 2003 Nomor 47 dan Tambahan Lembaran Negara Nomor 4286).

j. Undang-Undang Nomor 16 Tahun 2004 tentang Kejaksaan (Lembaran Negara Tahun 
2004 Nomor 67 dan Tambahan Lembaran Negara Nomor 4401).

k. Undang-Undang Nomor 7 Tahun 2006 tentang Pengesahan United Nations Convention Against Corruption, 2003 (Konvensi Perserikatan Bangsa-Bangsa Anti Korupsi, 2003) Lembaran Negara Tahun 2006 Nomor 32 dan Tambahan Lembaran Negara Nomor 4620.

1. Undang-Undang Nomor 46 Tahun 2009 tentang Pengadilan Tindak Pidana Korupsi (Lembaran Negara Tahun 2009 Nomor 155 dan Tambahan Lembaran Negara Nomor 5074).

m. Undang-Undang Nomor 48 Tahun 2009 tentang Kekuasaan Kehakiman (Lembaran Negara Tahun 2009 Nomor 157 dan Tambahan Lembaran Negara Nomor 5076).

n. Undang-Undang Nomor 8 Tahun 2010 tentang Pencegahan Dan Pemberantasan Tindak Pidana Pencucian Uang (Lembaran Negara Tahun 2010 Nomor 122 dan Tambahan Lembaran Nomor 5164).

2. Bahan hukum sekunder.

Dalam penelitian ini, bahan hukum sekunder terdiri dari:

a. Bahan pustaka yang berkaitan dengan hukum acara dan hukum materiil, khususnya mengenai tindak pidana korupsi dan pengembalian aset hasil tindak pidana korupsi.

b. Pendapat hukum/doktrin/teori-teori yang tertuang dalam buku teks, jurnal, laporan penelitian, dan karya ilmiah yang dipublikasikan maupun tidak dipublikasikan, yang membahas tentang pengembalian aset hasil tindak pidana korupsi.

c. Artikel di media massa cetak dan elektronik, khususnya mengenai kendala pengembalian aset hasil tindak pidana korupsi yang ditempatkan di dalam negeri maupun luar negeri.

3. Bahan hukum tersier.

Dalam penelitian ini, bahan hukum tersier diperoleh dari Kamus Bahasa Indonesia, Kamus Bahasa Inggris, Kamus Hukum, Ensiklopedi, indeks kumulatif, dan lain sebagainya yang berkaitan dengan obyek penelitian, serta sumber lainnya yang mendukung penelitian.

\subsection{Metode Pengolahan Data}

Dalam rangka untuk mendapatkan data-data yang valid dalam penelitian, penulis menggunakan teknik dokumenter, dengan mengadakan studi penelaahan arsip terhadap buku, literatur, catatan, laporan, dan putusan pengadilan yang berhubungan dengan materi penelitian.

Pengolahan bahan hukum dengan cara editing, yaitu pemeriksaan kembali bahan hukum yang diperoleh terutama dari kelengkapannya, kejelasan makna, kesesuaian, serta relevansinya dengan kelompok yang lain, kemudian melakukan coding, yaitu memberi catatan atau tanda yang menyatakan jenis sumber bahan hukum (literatur, undang-undang, dan dokumen); pemegang hak cipta (nama penulis dan tahun penerbitan), dengan mencantumkan sumber data baik dari media cetak maupun elektronik. Langkah selanjutnya adalah merekonstruksi bahan (reconstructing), yaitu menyusun ulang bahan hukum secara teratur, berurutan, logis, sehingga mudah dipahami dan diinterpretasikan. Langkah terakhir adalah sistematis bahan hukum (systematizing), yaitu menempatkan bahan hukum berurutan menurut kerangka sistematika bahasan berdasarkan urutan masalah.

\subsection{Metode Analisis Data}

Dalam penelitian ini, penulis menggunakan teknik analisis interaktif, sebagai berikut:

1. Reduksi data (data reduction).

Penulis melakukan analisis untuk mempertegas, memperpendek, membuat fokus, membuang halhal yang tidak penting, dan mengatur data sedemikian rupa, sehingga dapat menarik kesimpulan atau memperoleh pokok temuan.

2. Penyajian data (data display).

Penyajian data dilakukan dalam bentuk teks yang bersifat naratif dalam bentuk tabel, bagan, dan sejenisnya.

3. Penarikan kesimpulan dan verifikasi (conclusion drawing/verification).

Penulis melakukan verifikasi, analisis, dan mencari hubungan persamaan, hal-hal yang sering timbul, dan sebagainya yang dituangkan dalam kesimpulan tentatif mengenai strategi pemberantasan tindak pidana korupsi dan pengembalian aset hasil tindak pidana korupsi.

\section{HASIL DAN PEMBAHASAN}

\subsection{Strategi Pencegahan dan Pemberantasan Korupsi di Indonesia}

Sejarah menorehkan catatan panjang perjuangan bangsa Indonesia dalam rangka pemberantasan korupsi di Indonesia, namun perkembangan praktik korupsi dari tahun ke tahun semakin meningkat, baik dari segi kuantitas atau jumlah kerugian keuangan negara maupun dari segi kualitas yang semakin sistematis, canggih, serta ruang lingkup semakin meluas dalam seluruh aspek masyarakat (Syamsudin, 2007:183-184).

Menurut Atmasasmita (2016:115-116) ketidakberhasilan pemerintah dalam mencegah dan memberantas korupsi dapat dilihat dari 4 (empat) aspek, sebagai berikut:

1. Aspek hukum.

Aspek keberhasilan hukum bukan diukur dari jumlah perkara korupsi yang ditangani KPK dan Kejaksaan Agung, melainkan harus dilihat dari kualitas prosedur yang digunakan dalam menuntut dan menetapkan seseorang sebagai tersangka/terdakwa dan kualitas putusan pengadilan. Keberhasilan secara kuantitas ipso jure (menurut hukum) bukan berarti 
keberhasilan secara kualitatif, sebaliknya keberhasilan secara kualitatif mutatis mutandis keberhasilan secara kuantitatif.

2. Aspek ekonomi.

Keberhasilan secara kuantitatif tidak ipso facto (karena faktanya sendiri) memperkuat pertumbuhan ekonomi karena keberhasilan tersebut telah terbukti tidak berhasil mendorong pemerataan keadilan sosial.

3. Aspek sosial.

Tingkat kepuasan atau ketidakpuasan masyarakat terhadap pemberantasan korupsi berkolerasi langsung dengan kualitas pelayanan kepada publik di bidang perizinan, empati, dan simpati terhadap kejujuran, profesionalisme, dan integritas aparat penegak hukum.

4. Aspek politik.

Keberhasilan secara kuantitatif pemberantasan korupsi tidak ada pengaruhnya terhadap stabilitas politik, sebaliknya stabilitas politik sangat mempengaruhi komitmen dan sikap pemerintah dalam pemberantasan korupsi.

Hamzah (2007:261) berpendapat bahwa harus dicari penyebab korupsi itu dahulu, kemudian penyebab itu dihilangkan dengan cara prevensi, disusul dengan pendidikan (peningkatan kesadaran hukum) masyarakat disertai dengan tindakan represif (pemidanaan).

Dalam rangka mempercepat upaya pencegahan dan pemberantasan korupsi, Indonesia telah meratifikasi UNCAC Tahun 2003 melalui UndangUndang Nomor 7 Tahun 2006 tentang Pengesahan United Nations Convention Against Corruption, 2003 (Konvensi Perserikatan Bangsa-Bangsa Anti Korupsi, 2003). UNCAC Tahun 2003 menetapkan 3 (tiga) strategi utama pemberantasan korupsi, yaitu kriminalisasi (criminalisation), pengembalian hasil aset korupsi (asset recovery), dan kerja sama internasional (international cooperation). Ketiga strategi ini harus diterapkan secara seimbang, konsisten, sistematis, dan berkesinambungan.

Demi terwujudnya penyelenggaraan pemerintahan yang bersih dan bebas dari praktik korupsi, Pemerintah Indonesia memandang perlu menyusun 6 (enam) langkah strategi nasional pencegahan dan pemberantasan korupsi berdasarkan Lampiran Peraturan Presiden Nomor 5 Tahun 2012 tentang Strategi Nasional Pencegahan dan Pemberantasan Korupsi Jangka Panjang Tahun 20122025 dan Jangka Panjang Menengah Tahun 2012-2014 (Lembaran Negara Tahun 2012 Nomor 122), sebagai berikut:

1. Melaksanakan upaya-upaya pencegahan.

2. Melaksanakan langkah-langkah strategis di bidang penegakan hukum.

3. Melaksanakan upaya-upaya harmonisasi penyusunan peraturan perundang-undangan di bidang pemberantasan korupsi dan sektor terkait lain.

4. Melaksanakan kerja sama internasional dan penyelamatan aset hasil tipikor.
5. Meningkatkan upaya pendidikan dan budaya anti korupsi.

6. Meningkatkan koordinasi dalam rangka mekanisme pelaporan pelaksanaan upaya pemberantasan korupsi.

Strategi pemberantasan korupsi di Indonesia saat ini mengalami masa disorientasi yang fatal. Kondisi disorientasi ini yang memicu lahirnya ketidakpastian hukum dan krisis keadilan, yang pada gilirannya mengakibatkan kondisi iklim usaha dan ekonomi yang stagnan. Pemberantasan korupsi di Indonesia tidak mempertimbangkan 2 (dua) asas penting dalam suatu negara hukum (fundamental normen des rechtsstaat), yaitu asas proposionalitas dan asas subsidiaritas. Asas proposionalitas secara analogi dikatakan, "tidak perlu membakar lumbung hanya untuk menangkap tikus." Asas subsidiaritas dimaksudkan agar penegak hukum dalam penerapan ketentuan pidana wajib mempertimbangkan alternatif solusi hukum yang paling sedikit menimbulkan risiko, sehingga tujuan kepastian dan keadilan tercapai secara seimbang. Hal ini tidaklah mudah, mengingat penegak hukum di Indonesia merupakan penganut aliran positivisme (Atmasasmita, 2016:134).

Pusat Kajian Administrasi Indonesia (2007) menemukan ketidakefektifan dan ketidakefisienan pada lingkup utama instrumen pemberantas korupsi, yaitu dalam hal perundang-undangan antikorupsi dan lembaga penindak korupsi. Disharmonisasi antarperundang-undangan korupsi, yang memungkinkan enforcer tidak bisa menindak offender. Selain itu, terjadi persepsi yang berbeda antarlembaga perangkat penindak korupsi (enforcer) yang menjadikan sebuah kasus korupsi diinterpretasikan secara berbeda, sehingga memperlakukan pelanggar (offender) di mata hukum secara berbeda pula.

Pemberantasan korupsi (corruption fight back) merupakan salah satu sarana (tools) untuk menciptakan iklim pemerintahan yang sehat dan berwibawa. Menurut Myrdal sebagaimana dikutip Hamzah (2007:259), mengemukakan bahwa jalan untuk memberantas korupsi di negara-negara berkembang dengan cara menaikkan gaji pegawai rendah (dan menengah); menaikkan moral pegawai tinggi; dan legalisasi pungutan liar menjadi pendapat resmi atau legal.

Pradiptyo (2007:198-217) mengenalkan sebuah strategi pemberantasan korupsi yang didasarkan pada konsep game theory, yaitu inspection game. Inspection game merupakan salah satu permainan pada game theory, alat analisis yang mempelajari hubungan interaktif antara dua atau lebih agen yang rasional Secara garis besar, inspection game merupakan sebuah metode yang melihat hubungan atau interaksi antara penindak (enforcer) dan pelanggar (offender). Di mana keduanya akan berusaha untuk memaksimumkan payoffs-nya, sehingga masing-masing akan melakukan strategi terbaiknya. Payoff adalah the amount of benefit a player derives if a particular outcome happens". Enforcer dan offender akan menggunakan strategi 
terbaiknya untuk mendapatkan manfaat yang timbul jika hasil yang diharapkan terjadi.

Dalam penanganan tentang kejahatan ekonomi (crime economics), inspection game menjadi salah satu model yang sering digunakan. Tsebelis (1989:77-91) menyatakan bahwa peningkatan sanksi hukum tidak memengaruhi perilaku individu, tapi malah menurunkan probabilitas aparat untuk menegakkan hukum. Sama halnya pula, peningkatan hadiah agar tidak melanggar hukum (ukuran kesejahteraan) akan mengurangi jumlah penegakkan hukum, tetapi tidak untuk tingkat kejahatannya. Apa yang diungkapkan oleh Tsebelis ini merupakan kritik atas model yang digunakan Becker, yang didasarkan atas decision theory. Becker (1968:1-54) menyatakan bahwa keinginan individu untuk melakukan kejahatan dipengaruhi oleh probabilitas ditangkap dan beratnya sanksi hukum. Seorang individu (offender) lebih tidak mungkin untuk melakukan kejahatan jika probabilitasnya tertangkapnya tinggi dan adanya sanksi hukum yang berat. Pemikiran Becker ini merujuk pada analisis cost and benefit yang dialami oleh offender. Jika expected costs lebih besar expected benefits, pelanggaran tidak layak dilakukan, sedangkan jika expected costs lebih kecil expected benefits, pelanggaran layak dilakukan. Becker melengkapinya bahwa denda (fines) adalah jenis punishment terbaik.

Berdasarkan perhitungan Tsebelis menghasilkan beberapa proposisi terkait dengan strategi KPK dengan strategi warga negara untuk memaksimumkan pay off, sebagaimana dapat dilihat dalam tabel 5.

1. Proposisi pertama.

a. Seseorang akan melakukan tindak pidana korupsi, apabila ekspektasi kepuasan $\left(\mathrm{U}_{0}\right)$ tindak pidana korupsi lebih besar dari ekspektasi pengawasan dari KPK dalam menjatuhkan sanksi [ $\left.E_{C}\left(U_{D}+U_{R}\right)\right]$.

b. KPK akan melakukan penegakan hukum apabila ekspektasi manfaat dari menindak koruptor lebih besar dari ekspektasi biaya yang dikeluarkan $\left[\mathrm{E}\left(\mathrm{B}_{\mathrm{E}}>\left(\mathrm{C}_{\mathrm{E}}+\mathrm{p} \mathrm{C}_{\mathrm{S}}\right)\right)\right]$.

c. Probabilitas koruptor dari berbanding lurus dengan biaya penegakan hukum, tetapi memiliki hubungan terbalik dengan manfaatnya $\left[p^{*}=C_{E} /\left(B_{E}-C_{S}\right)\right]$.

d. Probabiltas dari KPK dalam melakukan penindakan memiliki hubungan yang positif dengan biaya yang dikeluarkan dan berbanding terbalik dengan hukuman yang harus dijalani koruptor $\left[q^{*}=U_{0} /\left(U_{D}+U_{R}\right)\right]$.

2. Proposisi kedua.

Apabila sanksi yang dijatuhkan lebih besar dari yang sebelumnya. Dibedakan menjadi 2 (dua) model, yaitu:

a. Menggunakan UU Tipikor saat ini.

Dengan pola sanksi hukuman tersebut, maka perilaku korupsi yang terjadi, yaitu:

1) Warga negara akan terdorong untuk melakukan tindak pidana korupsi dengan jumlah nilai lebih besar dari satu miliar rupiah. Artinya, keuntungan dari perbuatan korupsi akan lebih besar dari kesengsaraan pelaku menjalankan hukuman $\left(\mathrm{U}_{0}>\mathrm{U}_{\mathrm{D}}+\mathrm{U}_{\mathrm{R}}\right)$.

2) Mengisyaratkan bahwa warga negara yang memiliki kesempatan melakukan korupsi diwajibkan melakukannya karena pay off yang diterima akan sangat besar.

3) Meningkatkan probabilitas penegakan hukum dan peningkatan tindak pidana korupsi, sehingga keduanya akan bermain pada keadaan (korupsi, menindak), hal ini akan tetap bertahan selama keuntungan dari korupsi masih lebih besar dari sanksinya.

b. Melakukan perbaikan UU Tipikor.

1) Upaya dalam melakukan tindak pidana korupsi akan dipikirkan kembali untung ruginya.

2) Hukuman yang besar akan mampu menggeser ekspektasi korupsi seseorang untuk tidak melakukan tindak pidana korupsi.

3) Menurunkan probabilitas penegakan hukum oleh KPK dan menurunkan tindak pidana korupsi, hal ini masih akan memberikan manfaat bersih dari tindakan tersebut.

Untuk menyempurnakan metode inspection game dalam lingkup crime economics, Pradiptyo menggabungkan pendekatan Becker dan Tsebelis. Pradiptyo memodelkan fenomena pada penanganan kriminal selayaknya pendekatan Tsebelis, yaitu 2 pemain $2 \times 2$ one-shot game yang dimainkan oleh enforcer dan offender (publik). Enforcer dipahami sebagai bagian dari Criminal Justice Authority, seperti yang terdapat pada pendekatan Becker. Enforcer memiliki otoritas untuk mengatur tingkat hukuman. Enforcer juga bertugas untuk menegakkan hukum dan menjatuhkan hukuman. Setting ini walaupun enforcer seperti dalam pendekatan Becker, ternyata sesuai dengan model Tsebelis, yang mengasumsikan bahwa tingkat hukuman adalah exogenous. Pada saat yang sama Pradiptyo mengakomodasi model Becker dengan mengalokasi enforcer untuk menangkap kejahatan. Hasil penelitian Pradiptyo menunjukkan bahwa peningkatan tingkat hukuman akan mengurangi kemungkinan penegakan hukuman. Hasil ini terjadi sepanjang peraturan dapat meningkatkan disutilitas individu dalam menerima vonis hukum dari pengadilan dan peraturan tidak meningkatkan utilitas langsung dari pelanggaran. Terdapat kondisi di mana peningkatan hukuman akan mengurangi kemungkinan pelanggaran.

\subsection{Tahapan Pengembalian Aset Hasil Tindak Pidana Korupsi}

Upaya pengembalian aset merupakan keseluruhan rangkaian yang terdiri dari pelacakan atau penelusuran, upaya hukum perampasan, dan upaya pemulangan, yang tiap-tiap tahapannya membutuhkan kerja sama internasional. Pada 
umumnya, tahapan proses pengembalian aset dapat dibagi menjadi pelacakan, pembekuan, penyitaan, perampasan, pemeliharaan, atau pengelolaan aset di negara aset berada), pengembalian aset yang dicuri korban kejahatan (negara untuk perkara korupsi), dan pemeliharaan aset di negara di mana aset tersebut berasal. Dalam beberapa negara, terdapat proses prapenyitaan sebelum dilakukan penyitaan atas suatu aset.

Rangkaian pengembalian aset hasil korupsi, dapat ditempuh melalui beberapa tahapan, yaitu pelacakan, pembekuan, perampasan, dan pengembalian (Utama, 2013:63-120), sebagai berikut:

1. Pelacakan (identifikasi).

Tujuan pelacakan adalah untuk mengindentifikasi aset, lokasi penyimpanan aset, bukti kepemilikan aset, dan hubungannya dengan tindak pidana yang dilakukan. Selama tahap pelacakan, para investigator mengidentifikasi informasi dan mengumpulkan bukti-bukti yang relevan untuk menemukan semua aset yang tersembunyi baik di dalam negeri maupun di luar negeri. Keberhasilan pelacakan tindak pidana korupsi di sektor publik dan tindak pidana ekonomi pada umumnya, sangat bergantung pada kemampuan investigator dalam mencari jejak kepemilikan uang dan aset-aset yang diperoleh secara tidak sah atau mencari pelakunya. Investigator harus mengetahui cara menemukan aset-aset yang disembunyikan, bagaimana mengindentifikasikan kepentingan kepemilikan aset yang dikamuflase dengan melakukan perubahan bentuk dan sifat kepemilikan (Schroeder, 2001:29). Tiap-tiap instansi atau aparat penegak hukum terkait upaya pengembalian aset mempunyai tahapan pelacakan dengan karakter atau ciri yang berbeda, sehingga tidak ada pedoman baku yang diterapkan secara seragam, namun pada dasarnya proses pelacakan aset terbagi dalam beberapa tahapan sebagai berikut:

a. Perencanaan.

Perencanaan merupakan persiapan pelacakan aset dengan mempersiapkan waktu, anggaran, tim lapangan, alur koordinasi, dan lain-lain.

b. Identifikasi (profiling/locating).

Identifikasi merupakan langkah awal proses pelacakan yang difokuskan pada 2 (dua) hal, yaitu tersangka dan aset tersangka.

1) Identifikasi terhadap tersangka dan pihak-pihak yang ikut menikmati perolehan hasil korupsi, yaitu anggota keluarga, kerabat, teman, rekan bisnis, dan pihak-pihak terafiliasi.

2) Identifikasi pihak-pihak yang berperan dalam penempatan aset, yaitu para penyedia jasa keuangan, ekonomi, dan hukum, seperti konsultan pajak, auditor perusahaan, manajer investasi dan kekayaan, notaris, pengacara, serta pihak terkait baik di dalam maupun di luar negeri.

3) Identifikasi perkiraan pendapatan atau pemasukan tersangka dan keluarga inti. Identifikasi pola pengeluaran dikaitkan dengan identifikasi atas potensi penambahan aset tersangka dan keluarga inti.

4) Identifikasi riwayat tempat kediaman hukum (secara yuridis) dan tempat kediaman yang sesungguhnya (eigenlijke woonplaats).

5) Identifikasi riwayat serta pola perjalanan dinas maupun bisnis tersangka dan keluarga inti. Pola perjalanan tersebut dapat menjadi petunjuk tempat penyimpanan aset.

6) Identifikasi riwayat edukasi tersangka dan keluarga inti. Pelaku korupsi yang menyekolahkan anaknya ke luar negeri dengan fasilitas, seperti apartemen, kendaraan, dan lain-lain dapat diindentifikasi sebagai upaya penyelamatan serta penyembunyian aset.

7) Identifikasi pola transaksi keuangan tersangka dan keluarga inti.

8) Identifikasi pola gaya hidup.

c. Verifikasi.

Hasil identifikasi selanjutnya diverifikasi kepada lembaga resmi terkait, baik lembaga negara maupun lembaga swasta. Identifikasi yang tidak dapat diverifikasi harus dikumpulkan dan disimpan agar dapat dipergunakan sebagai petunjuk lainnya di kemudian hari.

d. Dokumentasi, pemetaan, dan klarifikasi aset. Dokumentasi fisik merupakan pengumpulan semua data, laporan tertulis, rekapitulasi seluruh aset, dan dokumen pendukung dari aset-aset yang dapat dijadikan objek analisis. Pemetaan dilakukan untuk mendeteksi besaran kerugian negara. Aset yang telah diverifikasi, selanjutnya diklasifikasi baik yang di bawah penguasaan atau kepemilikan perorangan atau badan hukum. Klasifikasi aset didasarkan pada benda bergerak, benda tidak bergerak, piutang tak berwujud, rekening bank, aliran utang, hak cipta atas suatu hal, dan seluruh hak-hak yang muncul kemudian hari, baik atas nama tersangka, nama anggota keluarga tersangka, maupun pihak lain yang terafiliasi.

e. Penelusuran (nexus mapping).

Aset yang telah diklasifikasi selanjutnya ditelusuri dengan hasil identifikasi dalam membangun jaringan nexus antara jenis aset, penempatan aset, dan para pihak.

f. Analisis akhir dilakukan terhadap hasil penelusuran. 
Analisis perlu menjabarkan secara detail tentang muatan dalam proses identifikasi awal, yaitu:

1) Analisis waktu (tempus) antara perolehan hasil korupsi dengan waktu terjadinya korupsi.

2) Analisis perolehan aset, bagaimana cara membeli atau membayarnya, siapa yang melakukan transaksi, dan di mana transaksi dilakukan.

3) Analisis dokumen, seperti dokumen perusahaan, asuransi, dan dokumen yang terkait gatekeeper.

g. Perampasan.

Pasal 1 angka 5 Undang-Undang Nomor 1 Tahun 2006 tentang Bantuan Timbal Balik dalam Masalah Pidana mendefinsikan perampasan sebagai upaya paksa pengambilalihan hak atas kekayaan atau keuntungan yang telah diperoleh, atau mungkin telah diperoleh oleh orang dari tindak pidana yang dilakukannya, berdasarkan putusan pengadilan di Indonesia atau negara asing. Hasil analisis (dalam bentuk laporan) dapat dijadikan dasar untuk melakukan upaya perampasan serta pengembalian aset, seperti pemblokiran rekening, penyitaan, maupun perampasan. Upaya pelacakan aset dapat dilihat melalui gambar 3 dan gambar 4 .

Langkah selanjutnya adalah menentukan lembaga mana yang mendapatkan kewenangan dari ketentuan hukum Indonesia untuk melakukan penyelidikan awal, pelacakan, dan penyidikan, yaitu:

a. Berdasarkan Kitab Undang-Undang Hukum Acara Pidana (KUHAP), yaitu Polisi, Kejaksaan Agung, dan Komisi Pemberantasan Korupsi. KPK dibentuk berdasarkan Undang-Undang Nomor 30 Tahun 2002 tentang Komisi Pemberantasan Tindak Pidana Korupsi. Dalam pelaksanaan tugasnya, KPK berpedoman kepada 5 (lima) asas, yaitu: kepastian hukum, keterbukaan, akuntabilitas, kepentingan umum, dan proporsionalitas. KPK bertanggung jawab kepada publik dan menyampaikan laporannya secara terbuka dan berkala kepada Presiden, DPR, dan BPK. Lembaga pemberantasan korupsi di Negara Singapura bernama Corrupt Practices Investigation Bureau (CPIB) didirikan pada tahun 1952; Di Negara Zambia, AntiCorruption Comission (ACC) didirikan pada tahun 1982; Di Negara Thailand, National Counter Corruption Comission (NCCC) didirikan pada tahun 1999; Di Negara Hong Kong, Independent Commission Against Corruption (ICAC) didirikan pada tahun 1974; Di Negara Kenya, Kenya Anti Corruption Comission (KACC) didirikan pada tahun 2003; Di Negara Madagaskar, Independent Anti
Corruption Bureau (BIANCO) didirikan pada tahun 2005; Di Negara Tanzania, Presidential Commission on Corruption (PCB) didirikan pada tahun 1991.

b. Berdasarkan Undang-Undang Nomor 8 Tahun 2010 tentang Pencegahan dan Pemberantasan Tindak Pidana Pencucian Uang, yaitu Polisi, Kejaksaan Agung, KPK, Badan Narkotika Nasional, Direktorat Jenderal Pajak, Direktorat Jenderal Bea dan Cukai, dan Kementerian Keuangan.

Menurut Conyngham (2002:2) untuk menjaga lingkup dan arah tujuan pelacakan atau investigasi menjadi fokus, maka otoritas yang melakukan investigasi atau melacak aset-aset tersebut bermitra dengan firma hukum dan firma akuntasi. Conyngham mengembangkan suatu metode investigasi yang disebutnya CAGE (Collated, Additional information accessed, intelligence Gathered, Evidence evaluated). Pendekatan metodologi ini dapat diketahui informasi mengenai alamat, pola perjalanan, yurisdiksi, struktur korporasi yang digunakan, dan informasi mengenai minat pribadi.

2. Membekukan dan mengamankan aset.

Pasal 2 huruf f United Nations Convention Against Corruption 2003 mendefinisikan pembekuan sebagai pelarangan sementara transfer, konversi, pelepasan, atau pemindahaan kekayaan, atau penempatan sementara kekayaan dalam pengawasan atau pengendalian berdasarkan perintah pengadilan atau pejabat berwenang lainnya (Freezing or seizure shall mean temporarily prohibiting the transfer, conversion, disposition or movement of property or temporarily assuming custody or control of property on the basis of an order issued by a court or other competent authority). Pengertian dan pemahaman yang sama digunakan oleh peraturan perundang-undangan di Indonesia dalam menyebut istilah pembekuan (freezing) adalah pemblokiran (restraint) dan penundaan transaksi (suspending transaction). Perintah pembekuan dari badan yang berwenang negara korban harus memenuhi 2 (dua) syarat, sebagai berikut:

a. Perintah tersebut harus mengandung dasar yang beralasan, sehingga badan yang berwenang negara penerima yakin bahwa terdapat alasan-alasan yang cukup untuk melakukan tindakan tersebut.

b. Aset yang dimintakan pembekuan dan perampasan merupakan objek perintah yang dikeluarkan oleh otoritas yang berwenang.

Pejabat terkait yang mendapatkan kewenangan dari ketentuan hukum Indonesia untuk melakukan pembekuan, yaitu:

a. Berdasarkan Pasal 29 ayat (4) Undang-Undang Nomor 20 Tahun 2001 tentang Perubahan atas Undang-Undang Nomor 31 Tahun 1999 tentang Pemberantasan Tindak Pidana Korupsi, yaitu penyidik, penuntut umum, atau hakim dapat 
meminta kepada bank untuk memblokir rekening simpanan milik tersangka atau terdakwa yang diduga hasil dari korupsi.

b. Berdasarkan Pasal 71 ayat (1) Undang-Undang Nomor 8 Tahun 2010 tentang Pencegahan dan Pemberantasan Tindak Pidana Pencucian Uang, yaitu penyidik, penuntut umum, atau hakim yang berwenang pihak pelapor untuk melakukan pemblokiran harta kekayaan yang diketahui atau patut diduga merupakan hasil tindak pidana korupsi dari setiap orang yang telah dilaporkan oleh Pusat Pelaporan dan Analisis Transaksi Keuangan (Indonesian Financial Transaction Reports and Analysis Center) kepada penyidik, tersangka, atau terdakwa. PPATK merupakan lembaga sentral (focal point) yang mengkoordinasikan pelaksanaan upaya pencegahan dan pemberantasan tindak pidana pencucian uang di Indonesia. Dalam dunia internasional, PPATK merupakan suatu Financial Intelligence Unit yang memiliki tugas dan kewenangan untuk menerima laporan transaksi keuangan, melakukan analisis atas laporan transaksi keuangan, dan meneruskan hasil analisis kepada lembaga penegak hukum.

c. Berdasarkan Peraturan Bank Indonesia Nomor 2/19/PBI/2000 tentang Persyaratan dan Tata Cara Pemberian Perintah atau Izin Tertulis Membuka Rahasia Bank, menentukan bahwa setiap pemblokiran, penundaan, atau pembekuan terhadap rekening tersangka atau terdakwa oleh polisi, penuntut umum, atau hakim dapat dilaksanakan tanpa izin dari Gubernur Bank Indonesia.

Setelah mengindentifikasi, penyidik harus membekukan semua aset dan rekening yang dicurigai guna memastikan aset dan rekening tidak dipindahkan kepemilikan yang baru atau yang sebelumnya tidak terindentifikasi. Upaya ini membutuhkan koordinasi dengan pengadilan yang berwenang untuk bekerja sama. Setelah pihak terkait memberikan kewenangan untuk melakukan tindakan, penyidik dan petugas penegak hukum dapat bergerak untuk membekukan aset, kemudian mulai bekerja sama dengan pengadilan yang berwenang untuk mengamankan dan melakukan pengamanan aset pada tahap-tahap berikutnya dalam upaya pengembalian aset.

3. Perampasan (forfeiturure).

Pasal 2 huruf g UNCAC 2003, mendefinisikan perampasan yang meliputi pengenaan denda, bilamana dapat diberlakukan, berarti pencabutan kekayaan untuk selama-lamanya berdasarkan perintah pengadilan atau pejabat berwenang lainnya (confiscation, which includes forfeiture where applicable, shall mean the permanent deprivation of property by order of a court or other competent authority). Dasar hukum perampasan aset hasil tindak pidana korupsi ditentukan dalam
Pasal 38 B ayat (2) Undang-Undang Nomor 20 Tahun 2001 tentang Perubahan atas UndangUndang Nomor 31 Tahun 1999 tentang Pemberantasan Tindak Pidana Korupsi. Upaya perampasan dapat dilakukan di negara tempat koruptor berada atau di wilayah aset tersebut disimpan. Pada umumnya diperlukan putusan pengadilan untuk melakukan perampasan. Penuntut Umum (KPK atau Kejaksaan Agung) memiliki peran yang besar dalam menjalankan tahap perampasan sebagai bagian dari proses pengembalian aset. Dalam beberapa kasus, otoritas sentral asing membutuhkan suatu instruksi resmi atau fatwa yang diterbitkan oleh Mahkamah Agung untuk meyakinkan pemerintah setempat. Terdapat beberapa alternatif dalam melakukan upaya perampasan, baik secara perdata, pidana, maupun administratif.

4. Pemulangan (repatriation).

Pemulangan merupakan langkah terakhir dari upaya pengembalian aset. Pembiayaan terkait proses pengembalian aset biasanya diambil dari jumlah aset yang berhasil dirampas dan terdapat sistem bagi hasil di antara kedua negara. Kerjasama yang dilakukan oleh Kejaksaan Agung, KPK, atau otoritas pusat dengan Kementerian Keuangan dapat membentuk suatu peran yang signifikan dalam melaksanakan pemulangan terhadap aset hasil tindak pidana korupsi.

\subsection{Realisasi Pengembalian Aset}

Salah satu contoh pengembalian aset oleh Pemerintah Indonesia adalah kasus Al-Warraq dan Rizvi.

1. Kasus Posisi:

Hesham Talaat Mohamed Besheer Al-Warraq (Terdakwa I) lahir di Kairo Mesir pada tanggal 12 April 1958 dan Rafat Ali Rizvi (Terdakwa II) lahir di Pakistan pada tanggal 22 Oktober 1960. Pada tahun 2001 s.d. 2008, bertempat di kantor Bank Century Intervest Corporation Internasional Tbk. dan/atau di kantor PT Bank Century Gedung Sentral Senayan II, Jalan Asia Afrika Nomor 8 Jakarta Pusat, melakukan atau turut serta melakukan, secara melawan hukum memperkaya diri sendiri atau orang lain atau suatu korporasi yang dapat merugikan keuangan negara atau perekonomian negara dengan cara melakukan transaksi pembelian, penempatan, dan/atau pertukaran surat-surat berharga valuta asing (SSB valas) Bank CIC. Sebagian surat berharga dimaksud merupakan surat berharga yang tergolong dalam structured product yang tidak memiliki peringkat, tidak memiliki harga pasar dan memberikan imbal hasil yang rendah, sehingga pada saat surat berharga jatuh tempo, Bank CIC tidak menerima dana secara tunai melainkan justru dibayar dengan saham perusahaan Global Opportunities Fund yang dimiliki Terdakwa II. Bank Pikko dan Danpac juga mengalami permasalahan pembelian/pertukaran 
surat-surat berharga, sehingga pada tanggal 6 Desember 2004 dilakukan merger atas ketiga bank tersebut dan berganti nama menjadi PT Bank Century Tbk. SSB valas yang berkualitas buruk yang sebelumnya berasal dari Bank CIC berlanjut menjadi beban Bank Century yang mengakibatkan kondisi keuangan Bank Century memburuk dan dikategorikan tidak sehat/macet. Terhadap kondisi ini, Bank Indonesia meminta Bank Century untuk menjual SSB tersebut dan mewajibkan untuk menambah modal. Pada tanggal 4 Oktober 2005, Terdakwa I dan II menandatangani Letter of Commitment (LoC) yang pada pokoknya menyatakan kesanggupan bertanggungjawab untuk menyelesaikan permasalahan permasalahan likuiditas bank dan untuk menjual SSB valas hingga batas waktu tanggal 31 Desember 2005. Dengan adanya permasalahan ini maka Bank Indonesia melakukan pemeriksaan/investigasi terhadap Bank Century bahwa pertukaran SSB Bank Century telah mengalami kesulitan likuiditas dan solvabilitas. Kondisi keuangan Bank Century semakin menurun ditambah pertimbangan likuiditas dan penurunan permodalan, maka Bank Indonesia memutuskan memberikan Fasilitas Pendanaan Jangka Panjang (FPJP). Pada tanggal 15 Oktober 2008, Terdakwa I dan II menandatangani Letter of Commitment (LoC) kepada Bank Indonesia untuk menyelesaikan permasalahan SSB tersebut.

2. Dakwaan:

- Pasal 2 ayat (1) jo. Pasal 18 Undang-Undang Nomor 20 Tahun 2001 tentang Perubahan Atas Undang-Undang Nomor 31 Tahun 1999 tentang Pemberantasan Tindak Pidana Korupsi jo. Pasal 55 ayat (1) KUHP.

- Pasal 3 ayat (1) huruf g Undang-Undang Nomor 25 Tahun 2003 tentang Perubahan Atas Undang-Undang Nomor 15 Tahun 2002 tentang Tindak Pidana Pencucian Uang jo. Pasal 55 ayat (1) KUHP.

3. Amar Putusan Pengadilan Negeri Jakarta Pusat Nomor 339/PID.B/2010/PN.JKT.PST tanggal 30 November 2010:

- Menyatakan Terdakwa I dan II yang diadili secara in absentia terbukti secara sah dan meyakinkan bersalah melakukan tindak pidana korupsi dan tindak pidana pencucian uang secara bersama-sama;

- Menjatuhkan pidana terhadap Terdakwa I dan II dengan pidana penjara masing-masing 15 (lima belas) tahun;

- Membebankan kepada terdakwa untuk membayar uang pengganti yang dibayar secara tanggung renteng sebesar Rp3.115. 889.000.000,00 (tiga triliun seratus lima belas miliar delapan ratus delapan puluh sembilan juta rupiah), apabila para terdakwa tidak membayar uang pengganti selama 1 (satu) bulan setelah perkara ini mempunyai kekuatan hukum tetap, maka harta bendanya dapat disita oleh jaksa untuk menutupi uang pengganti tersebut dan apabila para terdakwa tidak mempunyai harta benda yang mencukupi untuk membayar uang pengganti dipidana dengan pidana penjara selama 5 (lima) tahun penjara;

- Menjatuhkan pidana denda terhadap masingmasing terdakwa sebesar Rp15.000.000.000, 00 (lima belas miliar rupiah), subsidair 6 (enam) bulan kurungan;

- Membebankan kepada para terdakwa untuk membayar biaya perkara masing-masing sebesar Rp.10.000,00 (sepuluh ribu rupiah).

Aset Bank Century diketahui berada di 14 (empat belas) negara, yaitu Inggris, Swiss, Singapura, Hongkong, Bahama, Bahrain, Guernsey, New Jersey, Australia, Luxemburgo, Maurithius, Kuba, Saudi Arabia, dan Uni Emirat Arab. Aset Bank Century yang tersebar di 14 (empat belas) negara tersebut, hanya 4 (empat) negara yang memberikan respon secara positif, yaitu Inggris, Swiss, Singapura, dan Hongkong. Selain dalam bentuk tunai, aset tersebut juga dikonversi dalam bentuk saham. Total keseluruhan aset Bank Century yang tersebar tersebut nilainya diperkirakan mencapai Rp.14.000.000.000.000,00 (empat belas triliun rupiah), dengan perincian di UBS AG Bank Hongkong sebesar USD 19,250,000; Standard Chartered Bank sebesar USD 650,000,000 dan SGD 400,000; Swiss sebesar USD 220,000; British Virgin Island (Inggris) sebesar USD 872,000; Kuba sebesar USD 14,800,000; dan New Jersey sebesar USD 16,500,000 (Liputan 6, 2013). Pemerintah Indonesia berhasil menyelamatkan aset Bank Century di dalam negeri sebesar Rp295.000.000.000,00 (dua ratus sembilan puluh lima miliar rupiah) yang sebagian besar aset tersebut berasal dari aset PT Antaboga dengan total aset sebesar Rp11.000.000.000.000,00 (sebelas triliun rupiah) (Merdeka, 2014). Tim Terpadu Pencari Terpidana dan Tersangka Tindak Pidana Korupsi yang merupakan satuan kerja lintas departemen di bawah koordinasi Wakil Jaksa Agung, terdiri dari unsur-unsur Kejaksaan Agung; Kemenko Polhukam (Deputy III/Menko Polhukam Bidang Hukum dan HAM); Departemen Hukum dan HAM (Ditjen Administrasi Hukum Umum dan Ditjen Imigrasi); Kepolisian Negara (Bareskrim dan NCB Interpol Indonesia); Departemen Luar Negeri (Ditjen Politik Hukum Keamanan dan Kewilayahan); dan Unsur PPATK berupaya mengejar aset PT Bank Century, Tbk., yang berada di luar negeri. Pengadilan Tinggi Daerah Administratif Khusus Hong Kong telah mengabulkan permohonan pemerintah Indonesia untuk menyita sebagian aset Terpidana Rafat Ali Rizvi dan Hesham Al-Warraq sebesar USD 4,076,121 (empat juta tujuh puluh enam ribu seratus dua puluh satu dolar Amerika Serikat) atau sekitar Rp48.000.000.000,00 (empat puluh delapan miliar rupiah). Pemerintah Indonesia juga telah berupaya meminta agar Pemerintah Swiss membekukan uang atas nama Rafat Ali Rizvi dan Hesham Al-Warraq. 
Pembekuan itu terkendala oleh sistem hukum di negara tersebut. Menurut sistem hukum Negara Swiss, aset Bank Century bukan merupakan hasil tindak pidana, melainkan masalah administrasi atau kasus perdata (https://nasional.kompas.com/ read/ 2011/ 02/ 07/19011661/Darmono. Aset. Century. Ada. di. Swiss). Oleh karena itu, Pemerintah Indonesia berupaya meminta bantuan pada Bank Dunia dalam upaya membekukan aset Bank Century (kini Bank Mutiara) di Swiss.

Ngonzi N. Okonjo-Iweala selaku Direktur Eksekutif Bank Dunia dan Yury Fedotov selaku Direktur Eksekutif UNODC, menekankan bahwa pengembalian aset perolehan hasil kejahatan merupakan proses yang sulit, bahkan dalam keadaan yang ideal sekalipun, upaya pengembalian aset merupakan proses kompleks dan multidisiplin (Mariano, 2003:335).

Pemerintah Indonesia seharusnya berkaca dari keberhasilan pengembalian aset dalam kasus Sani Abacha dan Vladimiro Montesinos. Kasus Abacha dan Montesinos dianggap sukses karena sebagian besar aset hasil tindak pidana korupsi telah berhasil dikembalikan. Kasus Abacha dan Montesinos merupakan salah satu contoh adanya kemauan politik yang kuat dari Pemerintah Nigeria dan Peru (Ramelan, 2012:15-17). Hal ini menunjukkan bahwa bukanlah tidak mungkin untuk melakukan upaya pengembalian aset hasil tindak pidana korupsi (Utama, 2013:9).

\subsection{Faktor Yang Menjadi Kendala Dalam Pelaksanaan Pengembalian Aset Hasil Korupsi Transnasional}

Pada kenyataannya aset hasil tindak pidana korupsi yang dilarikan ke luar negeri dan aset yang berhasil dikembalikan ke Indonesia perbedaannya sangat besar. Hal ini tidak terjadi begitu saja, terdapat permasalahan-permasalahan yang seringkali muncul dan menjadi faktor utama yang menjadi kendala dalam proses asset recovery, sebagai berikut:

1. Perbedaan sistem hukum dengan negara di mana aset curian disimpan.

Perbedaan mendasar common law dan civil law, terutama dalam sistem peradilan pidana, yaitu:

a. Due Process Model (DPM), menitikberatkan pada perlindungan HAM bagi tersangka, sehingga menimbulkan birokrasi yang cukup panjang dalam peradilan pidana. DPM diumpamakan seperti orang yang sedang melakukan lari gawang.

b. Crime Control Model (CCM), yang menekankan efisiensi dan efektivitas peradilan pidana dengan berlandaskan asas praduga bersalah (presumption of guilt). CCM diumpamakan seperti sebuah bola yang digelindingkan tanpa penghalang (Atmasasmita, 2011:7-12).

2. Perbedaan terminologi dan definisi.

Indonesia memiliki definisi yang terlalu luas untuk korupsi, contohnya mendefinisikan tindak pidana penyuapan masuk dalam kategori korupsi, sedangkan negara lain memberikan perlakukan yang berbeda antara penyuapan, pencucian uang, dan korupsi (Sunarso, 2009:228).

3. Sistem kerahasiaan perbankan.

Harta hasil tindak pidana korupsi dilindungi oleh aturan kerahasiaan bank (bank secrecy) yang umumnya diterapkan pada negara-negara maju tempat aset hasil tipikor disimpan, antara lain Austria, Singapura, Cayman Islands, dan Liechtenstein (Zachrie dan Wijayanto, 2010).

4. Perjanjian antar negara.

Permasalahan pengembalian aset apabila antara Negara Peminta (Requesting State) dan Negara Diminta (Requested State) belum memiliki perjanjian bilateral, seperti Ekstradisi dan Mutual Legal Assistance (Atmasasmita, 2016:264).

5. UNCAC Tahun 2003 belum secara memadai (adequate) berkontemplasi dalam peraturan perundang-undangan di Indonesia.

Kajian analisis kesenjangan (gap analysis study), menunjukkan bahwa sejumlah penyesuaian perlu segera dilakukan untuk memenuhi klausulklausul di dalam UNCAC Tahun 2003, terkhusus bidang kriminalisasi dan peraturan perundangundangan (Lampiran Peraturan Presiden Nomor 55 Tahun 2012).

6. Proses pengembalian aset hasil tindak pidana korupsi memerlukan mekanisme dan prosedur panjang, biaya besar, dan sumber daya manusia yang tidak limitatif (Adji, 2009:151).

7. Memerlukan putusan pengadilan yang dapat menghubungkan antara aset yang bersangkutan dengan tindak pidana.

Aset hasil tindak pidana korupsi yang disimpan di negara lain dapat dibekukan dan/atau dikembalikan, maka diperlukan nama dan keterangan spesifik mengenai aset tersebut, yang seringkali tidak disebutkan di dalam putusan pengadilan (Prasasthi, 2011:9).

8. Penyalahgunaan kekuasaan.

Penyalahgunaan kekuasaan (abuse of power) melibatkan upper economic class maupun politik sebagai upper power class yang bersinergi dengan kekuatan politik, ekonomi, dan birokrasi (Musahib, 2015:6).

9. Ketidaksediaan negara maju untuk membantu upaya pengembalian aset (KHN, 2007).

10. Lemahnya kerja sama antar institusi terkait pengembalian aset (Utama, 2013:53).

Memerlukan konsesus antara yang mengajukan permohonan (Kejaksaan Agung atau KPK) dengan Kementerian Hukum dan HAM. Proses meraih konsensus ini seringkali terhambat oleh ego sektoral dan kepentingan politik masing-masing lembaga, sehingga memerlukan waktu yang lama dan pada akhirnya upaya tersebut tidak berhasil.

11. Lemahnya kemauan politik (political will) dan komitmen pemerintah (Listya, 2003:25).

\subsection{Elemen Keberhasilan Pengembalian Aset Hasil Tindak Pidana Korupsi}


Dalam melakukan upaya pengembalian aset berbagai mekanisme tersedia, kunci keberhasilan berada pada tiap-tiap masing negara, sehingga tidak dapat ditentukan mekanisme mana yang terbaik. Menurut Utama (2013:173-180), elemen keberhasilan dalam melakukan upaya pengembalian aset hasil tindak pidana korupsi harus memperhatikan beberapa faktor sebagai berikut:

1. Perspektif atas pendekatan penegakan hukum di Indonesia masih berfokus terhadap pemidanaan atas pelaku (in personam), bukan merampas aset hasil kejahatan.

2. Perlunya perangkat hukum nasional maupun internasional yang lebih luas dalam mengatur pengembalian aset. Perangkat hukum menjadi kerangka (framework) mengenai langkahlangkah apa saja yang harus dilakukan.

3. Integritas penegak hukum untuk selalu mengutamakan kepentingan publik menjadi prasyarat utama agar aset yang dikembalikan berada pada pemilik asalnya.

4. Kerja sama yang intensif dan berkesinambungan antara lembaga penegak hukum baik di tingkat nasional, bilateral, maupun multilateral. Untuk melakukan suatu proses pengembalian aset membutuhkan tim inti (core team) dan gugus tugas (task force) yang memiliki keahlian khusus yang berfungsi sebagai motor utama penyelidikan dan penindakan terhadap upaya pengembalian aset.

5. Kemauan politik (political will) yang konsisten dan komitmen kuat dari pemerintah.

6. Dukungan internasional termasuk dukungan negara tempat penyimpanan aset hasil korupsi. Dukungan ini diperlukan sejak tahap preventif sebagai criminal policy.

7. Payung hukum internasional.

Indonesia telah meratifikasi United Nations Convention Against Corruption (UNCAC), United Nations Convention Against Against Transnational Organized Crime (UNTOC), Asean Mutual Legal Assistance (AMLAT), namun Indonesia belum menjadi negara anggota Organisation for Economic Co-operation and Development (OECD).

8. Menindaklanjuti kerja sama bilateral dengan negara-negara tertentu dalam menangani kasus korupsi, meliputi ekstradisi, pengembalian aset hasil tindak pidana korupsi, dan penyerahan aset milik terpidana lainnya.

9. Penerapan standar pertukaran informasi otomatis (Automatic Exchange of Information). AEoI merupakan sistem yang mendukung adanya pertukaran informasi rekening wajib pajak antar negara pada waktu tertentu secara periodik, sistematis, dan berkesinambungan dari negara sumber penghasilan atau tempat menyimpan kekayaan, kepada negara residen wajib pajak.

10. Membuka kemungkinan dalam hukum pidana Indonesia melakukan penyelesaian hukum di luar proses pengadilan (afdoening buiten process) terhadap kasus korupsi tertentu.
11. Sinkronisasi dan harmonisasi peraturan perundang-undangan. Ratifikasi yang tidak ditindaklanjuti dengan harmonisasi dan pelaksanaan ketentuan yang ada dalam konvensi, akan menimbulkan dampak bagi bangsa Indonesia dalam penanggulangan, pencegahan, dan pemberantasan korupsi di Indonesia.

12. Merevisi dan/atau mengganti peraturan perundang-undangan yang berlaku secara bertahap untuk disesuaikan dengan internationally accepted legal standard.

\section{KESIMPULAN}

Berdasarkan pembahasan yang telah diuraikan dan dihubungkan dengan analisis yang telah dirumuskan, maka dapat ditarik kesimpulan sebagai berikut:

1. Pencegahan dan pemberantasan korupsi di Indonesia belum mencerminkan suatu strategi yang bersifat sitematik, terencana, dan komprehensif, disebabkan ketiadaan keseimbangan antara tindakan pencegahan, penindakan, pengembalian aset hasil korupsi, dan kerja sama internasional yang menitikberatkan kepada prinsip resiprositas dan menjunjung tinggi sikap kebersamaan (cooperativeness). Inti persoalan dalam strategi pencegahan dan pemberantasan korupsi adalah terletak pada itikad baik (good faith), kesungguhan (seriousness), kemauan (willingness), dan kemampuan (ability) dari seluruh komponen bangsa.

2. Upaya pengembalian aset merupakan suatu proses yang sulit, bahkan dalam keadaan yang ideal sekalipun, upaya pengembalian aset merupakan proses kompleks dan multidisiplin. Adapun faktor-faktor yang menjadi kendala dalam pelaksanaan pengembalian aset hasil tindak pidana korupsi yang bersifat transnasional, yaitu:

a. Perbedaan sistem hukum

b. Perbedaan terminologi dan definisi.

c. Sistem kerahasiaan perbankan.

d. Perjanjian antarnegara.

e. UNCAC Tahun 2003 belum secara memadai berkontemplasi dalam peraturan perundangundangan di Indonesia.

f. Mekanisme dan prosedur panjang, biaya besar, dan sumber daya manusia yang tidak limitatif

g. Memerlukan putusan pengadilan yang dapat menghubungkan antara aset yang bersangkutan dengan tindak pidana.

h. Penyalahgunaan kekuasaan.

i. Ketidaksediaan negara maju untuk membantu upaya pengembalian asset.

j. Lemahnya kerja sama antarinstitusi terkait pengembalian aset.

k. Lemahnya kemauan politik dan komitmen pemerintah. 


\section{IMPLIKASI DAN KETERBATASAN}

Terdapat beberapa pasal dalam Undang-Undang tentang Pemberantasan Tindak Pidana Korupsi yang belum mengadopsi sejumlah ketentuan yang tercantum dalam UNCAC Tahun 2003, selain itu belum secara komprehensif dan rinci mengatur tentang pengembalian aset hasil tindak pidana korupsi, sehingga tidak memungkinkan pengembalian aset secara efektif dan efisien. Merujuk pada prinsip pacta sunt servanda yang menjadi prinsip utama dalam setiap perjanjian internasional, Pemerintah Indonesia berkewajiban melakukan harmonisasi dengan menyesuaikan peraturan perundang-undangan nasional dengan prinsip dan standar yang berlaku secara universal sebagaimana tercantum dalam UNCAC Tahun 2003, melalui pembaharuan hukum pidana dengan merevisi dan/atau mengganti Undang-Undang Nomor 20 Tahun 2001 tentang Perubahan atas Undang-Undang Nomor 31 Tahun 1999 tentang Pemberantasan Tindak Pidana Korupsi; membentuk Undang-Undang tentang Pengembalian Aset Hasil Tindak Pidana Korupsi; dan Peraturan Pelaksanaan yang mengatur mekanisme pengembalian aset termasuk mekanisme mengenai kerja sama internasional dalam pencegahan dan pemberantasan tindak pidana korupsi.

\section{DAFTAR PUSTAKA}

Sumber Buku

Adji, I. S. 2009. Korupsi dan Penegakan Hukum. Jakarta: Diadit Media.

Anwar, Yesmil dan Adang. 2008. Pembaruan Hukum Pidana. Jakarta: Grasindo.

Atmasasmita, Romli. 2016. Pemikiran Romli Atmasasmita tentang Pemberantasan Korupsi di Indonesia. Jakarta: Kencana.

2011. Sistem Peradilan Pidana Kontemporer. Jakarta: Kencana.

Direktorat Jenderal Pendidikan Tinggi. 2006. Pendidikan Anti Korupsi Untuk Perguruan Tinggi. Jakarta: Kementerian Pendidikan dan Kebudayaan RI.

Djaja, Ermansjah. 2010. Memberantas Korupsi Bersama $K P K$. Jakarta: Sinar Grafika.

Fleming, M. H. 2005. Asset Recovery and it is Impact on Criminal Behavior. Inggris: University College London.

Hamzah, Andi. 2007. Pemberantasan Korupsi Melalui Hukum Pidana Nasional dan Internasional. Jakarta: Grafindo Persada.

Jaya, N. S. P. 2008. Beberapa Pemikiran ke Arah Pengembangan Hukum Pidana. Bandung: Citra Aditya Bakti.

Kristian dan Yopi Gunawan. 2015. Tindak Pidana Korupsi, Kajian Terhadap Harmonisasi antara Hukum Nasional dan The United Nations Convention Against Corruption, Bandung: Refika Aditama.

Kusuma, M. W. 2001. Tegaknya Supremasi Hukum. Bandng: Remadja Rosda Karya.
Mochtar, Akil. 2006. Memberantas Korupsi, Efektivitas Sistem Pembalikan Beban Pembuktian dalam Gratifikasi. Jakarta: Q-Communication.Mulyana

Pusat Kajian Administrasi Internasional. 2007. Strategi Penanganan Korupsi di Negara-negara Asia Pasifik. Jakarta: Lembaga Administrasi Negara.

Rohim. 2008. Modus Operandi Tindak Pidana Korupsi. Depok: Pena Multi Media.

Soekanto, Soerjono dan Mamudji. 2001. Penelitian Hukum Normatif (Suatu Tinjauan Singkat). Jakarta: Rajawali Pers.

Soemodihardjo, R. D. 2008. Mencegah dan Memberantas Korupsi, Mencermati Dinamikanya di Indonesia. Jakarta: Prestasi Pustaka Publisher.

Suhartoyo. 2014. Implementasi Asas Equality Before the Law dalam Pemberantasan Tindak Pidana Korupsi Dapat Meningkatkan Kewaspadaan Nasional Guna Mempertangguh Ketahanan Nasional. Jakarta: Lembaga Ketahanan Nasional RI.

Sunarso, Siswanto. 2009. Ekstradisi \& Bantuan Timbal Balik dalam Masalah Pidana, Instrumen Penegakan Hukum Pidana Internasional. Jakarta: Rineka Cipta.

Sunyoto, Danang. 2013. Perilaku Organisasional: Teori, Kuesioner, dan Proses Analisis Data. Yogyakarta: Center for Academic Publishing Service.

Suradi. 2006. Korupsi dalam Sektor Pemerintahan dan Swasta Mengurai Pengertian Korupsi, Pendeteksian, Pencegahannya dan Etika Bisnis. Yogyakarta: Gava Media.

Utama, Paku. 2013. Memahami Asset Recovery \& Gatekeeper. Jakarta: Indonesian Legal Roundtable.

Yanuar, P. M. 2007. Pengembalian Aset Hasil Korupsi Berdasarkan Konvensi PBB Anti Korupsi 2003 dalam Sistem Hukum Indonesia. Bandung: Alumni.

Zachrie, Ridwan dan Wijayanto. 2010. Korupsi Mengorupsi di Indonesia: Sebab, Akibat, dan Prospek Pemberantasan. Jakarta: Gramedia.

Buku Terjemahan

Klitgaard, Robert. 2005. Membasmi Korupsi. (Alih Bahasa, Hermoyo). Jakarta: Yayasan Obor Indonesia.

Jurnal

Dreher, Axel dan Martin Gassebner. 2013. Greasing the Wheels? The Impact of Regulations and Corruption on Firm Entry. Public Choice. Volume 155 p 413-432.

Ayu, Rhety dan Anis Chariri. 2015. Money Laundering dan Keterlibatan Wanita (Artis): Tantangan Baru Bagi Auditor Investigative. Journal of Accounting. Volume 4 No.3 p 4.

Becker, G. S. 1968. Crime and Punishment: An Economic Approach," Journal of Political Economy. Volume 1 No. 13 p 1-54.

Houston, Douglas. 2007. Can Corruption Ever Improve an Economy? Cato Journal. Volume 27 No. 3 p 325-342. 
Lui, Francis. 1985. An Equilibrium Queuing Model of Bribery. Journal of Political Economy. Volume 93 No. 4 p 760.

Mariano dan Florentino Cuella. 2003. The Tenuous Relationship between the Fight against Money Laundering and the Disruption of Criminal Finance. The Journal of Criminal Law and Criminology. Volume 93 No. 2-3 p 311-466.

Musahib, A.R. 2015. Pengembalian Keuangan Negara Hasil Tindak Pidana Korupsi. e-Jurnal Katalogis. Volume 3 No.1 p. 1-9.

Nawatmi, Sri. 2016. Pengaruh Korupsi Terhadap Pertumbuhan Ekonomi, Studi Empiris Negaranegara Asia Pasifik. Jurnal Media Ekonomi dan Manajemen. Volume 31 No.1 p 15.

Pradiptyo, Rimawan. 2007. Does Punishment Matter? A Refinement of the Inspection Game. Review of Law and Economics. Volume 3 No. 2 p 198-219.

Prakarsa, Aliyth dan Yulia. 2017. Model Pengembalian Aset (Asset Recovery) Sebagai Alternatif Memulihkan Kerugian Negara dalam Perkara Tindak Pidana Korupsi. Jurnal Hukum PRIORIS. Volume 6 No. 1 p 31-45.

Prasasthi, S. A. 2011. Upaya Pemerintah Republik Indonesia dalam Bantuan Hukum Timbal Balik Untuk Masalah Pidana (Mutual Legal Assistance) Terhadap Pengembalian Aset di Luar Negeri Hasil Tindak Pidana Korupsi (Stolen Asset Recovery). Jurnal Opinio Juris. Volume 2 p 46.

Syamsudin, M. 2007. Korupsi dalam Perspektif Budaya Hukum. UNISIA. Volume XXX No. 64 p 183-194.

Treisman, D. 2000. The Causes of Corruption: A CrossNational Study. Journal of Public Economics. Volume 76 p 399-457.

Tsebelis, George. 1989. The Abuse of Probability in Political Analysis: The Robinson Crusoe Fallacy. The American Political Science Review, Volume 83 No. 1 p. 77-91.

Waluyo, Bambang. 2014. Optimalisasi Pemberantasan Korupsi di Indonesia. Jurnal Yuridis. Volume 1 No. 2 p 174-175.

Karya Ilmiah

Haswandi. 2016. Pengembalian Aset Tindak Pidana Korupsi Pelaku dan Ahli Waris Menurut Sistem Hukum Indonesia. Disertasi. Padang: Universitas Andalas.

Komisi Hukum Nasional. 2007. Catatan Komisi Hukum Nasional tentang Stolen Asset Recovery (StAR) Initiative. Seminar Pengkajian Hukum Nasional. Jakarta.

Listya, A. K. 2014. United Nations Convention Against Corruption dan Kerja Sama Mutual Legal Assistance on Asset Recovery antara Indonesia dan Swiss. Naskah Ringkas. Depok: Universitas Indonesia.

Pradiptyo, Rimawan. 2016. Dampak Sosial Korupsi. Modul Integritas Bisnis. Jakarta: Direktorat Pendidikan dan Pelayanan Masyarakat.

Ramelan. 2012. Laporan Akhir Naskah Akademik Rancangan Undang-Undang tentang Perampasan
Aset Tindak Pidana, Jakarta: Badan Pembinaan Hukum Nasional, Kementerian Hukum dan Hak Asasi Manusia.

Supandji, Hendrarman. 2009. Peningkatan Pencegahan Tindak Pidana Korupsi dalam Pelaksanaan Tugas Kejaksaan. Makalah. Semarang: UNDIP.

Syahmin, Elvani, dan Yuningsih. 2013. Pengembalian Aset Negara Hasil Tipikor Melalui Kerja Sama Timbal Balik Antar Negara. Laporan Penelitian Fundamental. Palembang: Universitas Sriwijaya.

Wiennata, P.P. 2014. Faktor-faktor Yang Mempengaruhi Pertumbuhan Ekonomi Pada Negara G-20 (Pembuktian Grease the Wheels Hypothesis). Skripsi. Semarang: Universitas Diponegoro.

Surat Kabar

Manan, Bagir. 2006. "Kedudukan Penegak Hukum dalam Sistem Ketatanegaraan Republik Indonesia". Majalah Hukum Varia Peradilan Edisi XXI No.243 p 4.

Schroeder, William. 2001. "How to Do Financial Asset Investigations: A Practical Guide for Private Investigators, Collections Personnel and Assets Recovery Specialists". The FBI Law Enforcement Bulletin.

Naskah dari Internet

Badan Pusat Statistik. 2017. Pertumbuhan Ekonomi Indonesia. https://www.bps.go.id/pressrelease/ 2017/ 08/ 07/ 1365/ pertumbuhan-ekonomiindonesia-triwulan-ii-2017.html/ diakses tanggal 5 November 2017.

Conyngham, John. 2002. Testimony of John Conyngham Esq Global Director of Investigations, Control Risks Group Limited Before the Committee on Financial Services Subcommittee on Financial Institutions and Consumer Credit, US House of Representatives. http://archives.financialservices.house.gov/med ia/pdf/050902jc.pdf/ diakses tanggal 5 November 2017.

Henderson, Vernon dan Ari Kuncoro. 2006. Corruption in Indonesia. http://www.brown. edu/ Departments/Economics/Faculty/henderson/pa pers/corruption120704.pdf, diakses tanggal 2 November 2017.

Indawati, Ninik. Pengembangan Mata Kuliah Pendidikan Anti Korupsi (Studi Evaluatif Tentang Efektivitas Kajian Literatur pada penelitian Pendidikan Anti Korupsi). http://repository. unikama.ac.id/855/1/CALL\%20F0R\%20PAPER S- UM - 24 - 25 \% 20 MAY \% 202016 -ninik.pdf/ diakses tanggal 7 November 2017.

Indonesia Corruption Watch. 2016. Kerugian Negara Akibat Korupsi 2015 Sebesar 3,1 Triliun, http:// www.antikorupsi.org/ id/ content/ kerugiannegara- akibat- korupsi- 2015- sebesar -31triliun/ diakses tanggal 3 November 2017.

Kompas. 2011. Darmono: Aset Century Ada di Swiss. https://nasional.kompas.com/read/2011/02/07 
/19011661/Darmono.Aset.Century.Ada.di.Swiss. diakses tanggal 18 Juli 2018.

Kompas. 2015. Korupsi Gerogoti Kekayaan Negara. https://nasional.kompas.com/read/2015/06/04 /15000031/korupsi.Gerogoti/ diakses tanggal 11 Juli 2018.

Kompas. 2016. Aliran Dana Gelap dari Indonesia Paling Besar ke Singapura dan China. http:// nasional. kompas.com/ read/ 2016/ 02/ 20/ 16443801/ Aliran.Dana. Gelap. dari. Indonesia. Paling. Besar. ke.Singapura.dan.China/ diakses tanggal 1 November 2017.

Liputan 6. 2013. Aset Robert Tantular US\$ 16 Juta di Jersey Tak Bisa Dicairkan. http://news.liputan6. $\mathrm{com} / \mathrm{read} / 659604 /$ aset- robert- tantular-us-16-jutadi-jersey-tak-bisa-dicairkan, diakses tanggal 18 Juli 2018.

Merdeka. 2014. Pemerintah Upayakan Aset Bank Century di Luar Negeri Kembali. https://www. merdeka.com/peristiwa/pemerintah- upayakanaset-bank-century-di-luar-negeri-kembali.htm/ diakses tanggal 18 Juli 2018.

Political \& Economic Risk Consultancy Ltd. 2018. PERC's 2018 Report on Corruption in Asia. http://www.asiarisk.com/subscribe/dataindx.ht $\mathrm{ml} /$ diakses tanggal 12 Juli 2018.

Stranas PPK. 2015. Latar Belakang. http://stranasppk. bappenas.go.id/latar-belakang.html/ diakses tanggal 12 Juli 2018.

Tempo. 2017. Sepanjang 2016, Negara Rugi Rp 3 Triliun Dari Kasus Korupsi. https:// nasional.tempo.co/ read / 852637/ sepanjang-2016-negara-rugi-rp3-triliun-dari-kasus-korup si/ diakses tanggal 1 November 2017.

Transparency International. 2018. Corruption Perceptions Index 2017. http://www.transparency.org/ news/ feature/ corruption_perceptions_index_2017 \#table/ diakses tanggal 12 Juli 2018.

Utama, Paku. 2008. Terobosan UNCAC dalam Pengembalian Aset Korupsi Melalui Kerjasama
Internasional. http://www.hukumonline.com/ berita/baca/hol19356/terobosan- uncac- dalampengembalian-aset-korupsi- melalui- kerjasamainternasional, diakses tanggal 8 Desember 2017.

Naskah Produk Kebijakan

Undang-Undang Dasar Negara Republik Indonesia Tahun 1945. Yogyakarta: Pustaka Yustisia.

Undang-Undang Republik Indonesia Nomor 8 Tahun 1981 tentang Hukum Acara Pidana. Jakarta: Bumi Aksara.

Undang-Undang Republik Indonesia Nomor 28 Tahun 1999 tentang Penyelenggaraan Negara Yang Bersih Dan Bebas Dari Korupsi, Kolusi, Dan Nepotisme. Jakarta: Visimedia.

Undang-Undang Republik Indonesia Nomor 20 Tahun 2001 tentang Perubahan Atas Undang-Undang Nomor 31 Tahun 1999 tentang Pemberantasan Tindak Pidana Korupsi. Bandung: Fokusindo Mandiri.

Undang-Undang Republik Indonesia Nomor 2 Tahun 2002 tentang Kepolisian Negara Republik Indonesia. Medan: Citra Umbara.

Undang-Undang Republik Indonesia Nomor 30 Tahun 2002 tentang Komisi Pemberantasan Tindak Pidana Korupsi. Jakarta: Gramedia.

Undang-Undang Republik Indonesia Nomor 17 Tahun 2003 tentang Keuangan Negara. Bandung: Fokus Media.

Undang-Undang Republik Indonesia Nomor 16 Tahun 2004 tentang Kejaksaan. Surabaya: Karina.

Undang-Undang Republik Indonesia Nomor 46 Tahun 2009 tentang Pengadilan Tindak Pidana Korupsi. Yogyakarta: Laksana. 


\section{LAMPIRAN}

Tabel 1. Political and Economic Risk Consultancy Ltd. Report on Corruption in Asia 2007-2017

\begin{tabular}{|l|c|c|c|c|c|c|c|c|c|c|c|}
\hline CoUNTRY & $\mathbf{2 0 0 7}$ & $\mathbf{2 0 0 8}$ & $\mathbf{2 0 0 9}$ & $\mathbf{2 0 1 0}$ & $\mathbf{2 0 1 1}$ & $\mathbf{2 0 1 2}$ & $\mathbf{2 0 1 3}$ & $\mathbf{2 0 1 4}$ & $\mathbf{2 0 1 5}$ & $\mathbf{2 0 1 6}$ & $\mathbf{2 0 1 7}$ \\
\hline Australia & 0.83 & 0.98 & 1.40 & 1.47 & 1.39 & 1.28 & 2.35 & 2.55 & 2.61 & 2.67 & 2.50 \\
\hline Cambodia & 9.10 & 8.50 & 8.10 & 8.30 & 9.27 & 6.83 & 7.84 & 8.00 & 7.75 & 7.75 & 8.13 \\
\hline China & 6.29 & 7.98 & 7.30 & 6.70 & 7.93 & 7.00 & 7.79 & 7.10 & 6.98 & 7.50 & 7.08 \\
\hline Hong Kong & 1.87 & 1.80 & 1.74 & 1.75 & 1.10 & 2.64 & 3.77 & 2.95 & 3.17 & 3.40 & 4.38 \\
\hline India & 6.67 & 7.25 & 6.50 & 8.23 & 8.67 & 8.75 & 8.95 & 9.15 & 8.01 & 8.13 & 7.25 \\
\hline Indonesia & 8.03 & 7.98 & 7.69 & 9.07 & 9.25 & 8.50 & 8.83 & 8.85 & 8.09 & 8.00 & 7.57 \\
\hline Japan & 2.10 & 2.25 & 2.63 & 2.63 & 1.90 & 1.90 & 2.35 & 2.08 & 1.55 & 3.00 & 3.55 \\
\hline Macau & 5.18 & 3.30 & 3.75 & 5.71 & 4.68 & 2.85 & 4.23 & 3.65 & 4.58 & 6.15 & 6.50 \\
\hline Malaysia & 6.25 & 6.37 & 7.00 & 6.05 & 5.70 & 5.59 & 5.38 & 5.25 & 4.96 & 6.95 & 6.78 \\
\hline Philippines & 9.40 & 9.00 & 7.68 & 8.25 & 8.90 & 9.35 & 8.28 & 7.85 & 7.43 & 7.05 & 6.85 \\
\hline Singapore & 1.20 & 1.13 & 0.92 & 0.99 & 0.37 & 0.67 & 0.74 & 1.60 & 1.33 & 1.67 & 1.90 \\
\hline South Korea & 6.30 & 5.65 & 4.97 & 4.88 & 5.90 & 6.90 & 6.98 & 7.05 & 6.28 & 6.17 & 6.63 \\
\hline Taiwan & 6.23 & 6.55 & 5.85 & 5.62 & 5.65 & 5.45 & 5.36 & 5.31 & 5.00 & 6.08 & 5.75 \\
\hline Thailand & 8.03 & 8.00 & 6.76 & 7.33 & 7.55 & 6.75 & 6.83 & 8.25 & 6.88 & 7.67 & 7.13 \\
\hline USA & 2.28 & 1.83 & 2.71 & 1.89 & 1.39 & 2.59 & 3.82 & 3.50 & 4.59 & 4.61 & 5.54 \\
\hline Vietnam & 7.54 & 7.75 & 7.40 & 7.13 & 8.30 & 7.75 & 8.13 & 8.73 & 8.24 & 7.92 & 7.90 \\
\hline
\end{tabular}

Sumber: Political \& Economic Risk Consultancy, Ltd.

Tabel 2. Rincian Bentuk Tindak Pidana Korupsi

\begin{tabular}{|c|c|c|c|c|c|c|c|}
\hline \multirow[t]{2}{*}{ NO. } & \multirow{2}{*}{$\begin{array}{l}\text { KELOMPOK } \\
\text { TIPIKOR }\end{array}$} & \multirow[t]{2}{*}{ KETERANGAN } & \multicolumn{3}{|c|}{$\begin{array}{l}\text { PIDANA PENJARA } \\
\text { (TAHUN) }\end{array}$} & \multicolumn{2}{|c|}{$\begin{array}{r}\text { PIDANA DENDA } \\
\text { (JUTA RUPIAH) }\end{array}$} \\
\hline & & & & MIN & MAX & MIN & MAX \\
\hline \multicolumn{8}{|c|}{ Kerugian Keuangan Negara } \\
\hline 1. & Pasal 2 & Memperkaya diri & $\begin{array}{l}\text { Seumur hidup, } \\
\text { pidana mati }\end{array}$ & 4 & 20 & 200 & 1.000 \\
\hline 2. & Pasal 3 & $\begin{array}{l}\text { Menyalahgunakan } \\
\text { wewenang }\end{array}$ & Seumur hidup & 1 & 20 & 50 & 1.000 \\
\hline \multicolumn{8}{|c|}{ Suap-Menyuap } \\
\hline 3. & Pasal 5 ayat (1) a & Menyuap pegawai negeri & & 1 & 5 & 50 & 250 \\
\hline 4. & Pasal 5 ayat (1) b & Menyuap pegawai negeri & & 1 & 5 & 50 & 250 \\
\hline 5. & Pasal 13 & $\begin{array}{l}\text { Memberi hadiah kepada } \\
\text { pegawai negeri }\end{array}$ & & & 3 & & 150 \\
\hline 6. & Pasal 5 ayat (2) & $\begin{array}{l}\text { Pegawai negeri } \\
\text { menerima suap }\end{array}$ & & 1 & 5 & 50 & 250 \\
\hline 7. & Pasal $12 \mathrm{a}$ & $\begin{array}{l}\text { Pegawai negeri } \\
\text { menerima suap }\end{array}$ & Seumur hidup & 4 & 20 & 200 & 1.000 \\
\hline 8. & Pasal $12 \mathrm{~b}$ & $\begin{array}{l}\text { Pegawai negeri } \\
\text { menerima suap }\end{array}$ & Seumur hidup & 4 & 20 & 200 & 1.000 \\
\hline 9. & Pasal 11 & $\begin{array}{l}\text { Pegawai negeri } \\
\text { menerima hadiah }\end{array}$ & & 1 & 5 & 50 & 250 \\
\hline 10. & Pasal 6 ayat (1) a & Menyuap hakim & & 3 & 15 & 150 & 750 \\
\hline 11. & Pasal 6 ayat (1) b & Menyuap advokat & & 3 & 15 & 150 & 750 \\
\hline 12. & Pasal 6 ayat (2) & $\begin{array}{l}\text { Hakim dan advokat } \\
\text { menerima suap }\end{array}$ & & 3 & 15 & 150 & 750 \\
\hline 13. & Pasal $12 \mathrm{c}$ & Hakim menerima suap & Seumur hidup & 4 & 20 & 200 & 1.000 \\
\hline 14. & Pasal $12 \mathrm{~d}$ & Advokat menerima suap & Seumur hidup & 4 & 20 & 200 & 1.000 \\
\hline \multicolumn{8}{|c|}{ Penggelapan dalam Jabatan } \\
\hline 15. & Pasal 8 & $\begin{array}{l}\text { Pegawai negeri } \\
\text { menggelapkan uang atau } \\
\text { membiarkan } \\
\text { penggelapan }\end{array}$ & & 3 & 15 & 150 & 750 \\
\hline
\end{tabular}




\begin{tabular}{|c|c|c|c|c|c|c|c|}
\hline 16. & Pasal 9 & $\begin{array}{l}\text { Pegawai negeri I } \\
\text { memalsukan buku }\end{array}$ & & 1 & 5 & 50 & 250 \\
\hline 17. & Pasal $10 \mathrm{a}$ & $\begin{array}{l}\text { Pegawai negeri I } \\
\text { merusakkan bukti }\end{array}$ & & 2 & 7 & 100 & 350 \\
\hline 18. & Pasal $10 \mathrm{~b}$ & $\begin{array}{l}\text { Pegawai negeri } \\
\text { membiarkan orang lain } \\
\text { merusakkan bukti }\end{array}$ & & 2 & 7 & 100 & 350 \\
\hline 19. & Pasal $10 \mathrm{c}$ & $\begin{array}{l}\text { Pegawai negeri } \\
\text { membantu orang lain } \\
\text { merusakkan bukti }\end{array}$ & & 2 & 7 & 100 & 350 \\
\hline \multicolumn{8}{|c|}{ Perbuatan Pemerasan } \\
\hline 20. & Pasal $12 \mathrm{e}$ & Pegawai negeri memeras & Seumur hidup & 4 & 20 & 200 & 1.000 \\
\hline 21. & Pasal $12 \mathrm{~g}$ & Pegawai negeri memeras & Seumur hidup & 4 & 20 & 200 & 1.000 \\
\hline 22. & Pasal $12 \mathrm{~h}$ & Pegawai negeri memeras & Seumur hidup & 4 & 20 & 200 & 1.000 \\
\hline \multicolumn{8}{|c|}{ Perbuatan Curang } \\
\hline 23. & Pasal 7 ayat (1) a & $\begin{array}{l}\text { Pemborong berbuat } \\
\text { curang }\end{array}$ & & 2 & 7 & 100 & 350 \\
\hline 24. & Pasal 7 ayat (1) b & $\begin{array}{l}\text { Pengawas proyek } \\
\text { membiarkan perbuatan } \\
\text { curang }\end{array}$ & & 2 & 7 & 100 & 350 \\
\hline 25. & Pasal 7 ayat (1) c & $\begin{array}{l}\text { Rekanan TNI/ Polri } \\
\text { berbuat curang }\end{array}$ & & 2 & 7 & 100 & 350 \\
\hline 26. & Pasal 7 ayat (1) d & $\begin{array}{l}\text { Pengawas rekanan } \\
\text { TNI/Polri berbuat curang }\end{array}$ & & 2 & 7 & 100 & 350 \\
\hline 27. & Pasal 7 ayat (2) & $\begin{array}{l}\text { Penerima barang } \\
\text { TNI/Polri membiarkan } \\
\text { perbuatan curang }\end{array}$ & & 2 & 7 & 100 & 350 \\
\hline 28. & Pasal $12 \mathrm{~h}$ & Pegawai negeri memeras & Seumur hidup & 4 & 20 & 200 & 1.000 \\
\hline \multicolumn{8}{|c|}{ Benturan Kepentingan dalam Pengadaan } \\
\hline 29. & Pasal $12 \mathrm{i}$ & $\begin{array}{l}\text { Pegawai negeri turut } \\
\text { serta dalam pengadaan } \\
\text { yang diurusnya }\end{array}$ & Seumur hidup & 4 & 20 & 200 & 1.000 \\
\hline \multicolumn{8}{|c|}{ Gratifikasi } \\
\hline 30. & Pasal 12B jo. 12C & $\begin{array}{l}\text { Pegawai negeri } \\
\text { menerima gratifikasi dan } \\
\text { tidak melapor }\end{array}$ & Seumur hidup & 4 & 20 & 200 & 1.000 \\
\hline
\end{tabular}

Sumber: Undang-Undang Nomor 20 Tahun 2001 tentang Perubahan atas Undang-Undang Nomor 31 Tahun 1999 tentang Pemberantasan Tindak Pidana Korupsi

Tabel 3. Hubungan Korupsi dan Perekonomian Indonesia

\begin{tabular}{|l|c|l|c|}
\hline \multirow{2}{*}{ Variabel } & \multicolumn{3}{c|}{ Indeks Persepsi Korupsi (1995-2015) } \\
\cline { 2 - 4 } & Korelasi Spearman & Hubungan & $\mathrm{N}$ \\
\hline Pertumbuhan Ekonomi & $-0.5638^{* * *}$ & Negatif signifikan & 21 \\
\hline Investasi (FDI) & $-0.7930^{* * *}$ & Negatif signifikan & 21 \\
\hline Pendapatan Per kapita & $-0.9147^{* * *}$ & Negatif signifikan & 21 \\
\hline Belanja Kesehatan Publik & $-0.7059^{* * *}$ & Negatif signifikan & 20 \\
\hline Kemiskinan & $0.7857^{* *}$ & Positif signifikan & 7 \\
\hline Kesenjangan kemiskinan (poverty gap) & $0.9033^{* * *}$ & Positif signifikan & 12 \\
\hline Pengangguran & 0.0378 & Positif signifikan & 21 \\
\hline
\end{tabular}

Catatan:

*** : signifikan pada alpha $=1 \%$

** : signifikan pada alpha $=5 \%$

* $\quad$ : signifikan pada alpha $=10 \%$

Sumber: Tranparency International dan World Bank 
Tabel 4. Perbandingan antara Undang-UndangNomor 20 Tahun 2001 dan UNCAC Tahun 2003

\begin{tabular}{|c|c|c|c|}
\hline NO. & KRITERIA & UNCAC TAHUN 2003 & $\begin{array}{c}\text { UNDANG-UNDANG } \\
\text { NOMOR } 20 \text { TAHUN } 2001\end{array}$ \\
\hline 1. & $\begin{array}{l}\text { Penyuapan } \\
\text { pejabat, publik } \\
\text { nasional. }\end{array}$ & $\begin{array}{l}\text { Diatur dalam Pasal } 15 \text { huruf a dan b } \\
\text { UNCAC. } \\
\text { Unsur-unsur tindak pidana Pasal } 15 \\
\text { huruf (a) UNCAC: } \\
\text { - } \quad \text { Dilakukan dengan sengaja. } \\
\text { - } \text { Memberikan janji tawaran, } \\
\text { pemberian yang tidak semestinya. } \\
\text { - } \quad \text { Secara langsung atau tidak } \\
\text { langsung. } \\
\text { - } \quad \text { Kepada pejabat publik nasional } \\
\text { atau badan lain, agar pejabat yang } \\
\text { bersangkutan bertindak tidak } \\
\text { sesuai dengan tugasnya. } \\
\text { Unsur-unsur tindak pidana Pasal } 15 \\
\text { huruf b UNCAC: } \\
\text { - Perbuatan itu dilakukan dengan } \\
\text { sengaja. } \\
\text { - Dilakukan oleh pejabat publik atau } \\
\text { orang atau badan lain. } \\
\text { - Meminta atau menerima manfaat } \\
\text { yang tidak semestinya. } \\
\text { - Baik secara langsung maupun tidak } \\
\text { langsung. } \\
\text { - Sehingga pejabat yang } \\
\text { bersangkutan bertindak tidak } \\
\text { sesuai dengan tugasnya. }\end{array}$ & $\begin{array}{l}\text { Diatur dalam Pasal } 5 \text { ayat (1) huruf a } \\
\text { dan b, Pasal } 5 \text { ayat (2), Pasal } 6 \text { ayat (1) } \\
\text { huruf a dan b, Pasal } 6 \text { ayat (2), Pasal } \\
\text { 11, Pasal } 12 \text { huruf a, b, c, dan d, serta } \\
\text { Pasal } 13 \text { UU Nomor } 20 \text { Tahun } 2001 .\end{array}$ \\
\hline 2. & $\begin{array}{l}\text { Penyuapan } \\
\text { pejabat publik } \\
\text { asing dan } \\
\text { organisasi } \\
\text { internasional } \\
\text { publik. }\end{array}$ & $\begin{array}{l}\text { Diatur dalam Pasal } 16 \text { ayat (1) UNCAC. } \\
\text { Unsur-unsur tindak pidana Pasal } 16 \\
\text { ayat (1) UNCAC: } \\
\text { - } \quad \text { Dengan sengaja. } \\
\text { - } \text { Memberikan janji, tawaran, atau } \\
\text { pemberian manfaat yang tidak } \\
\text { semestinya. } \\
\text { - } \quad \text { Secara langsung ataupun tidak } \\
\text { langsung. } \\
\text { - } \quad \text { Kepada pejabat publik asing atau } \\
\text { pejabat organisasi internasional } \\
\text { publik atau orang atau badan lain. } \\
\text { - } \quad \text { Agar pejabat yang bersangkutan } \\
\text { tidak bertindak sesuai dengan } \\
\text { tugas resminya. }\end{array}$ & $\begin{array}{l}\text { Pasal } 16 \text { ayat (1) UNCAC, belum } \\
\text { diimplementasikan ke dalam } \\
\text { peraturan perundang-undangan } \\
\text { nasional Indonesia. }\end{array}$ \\
\hline 3. & $\begin{array}{l}\text { Penggelapan, } \\
\text { penyalahgunaan, } \\
\text { atau } \\
\text { penyimpangan } \\
\text { lain atas kekayaan } \\
\text { oleh pejabat } \\
\text { publik. }\end{array}$ & $\begin{array}{l}\text { Diatur dalam Pasal } 17 \text { UNCAC. } \\
\text { Unsur-unsur tindak pidana Pasal } 17 \\
\text { UNCAC: } \\
\text { - } \quad \text { Dilakukan dengan sengaja. } \\
\text { - } \quad \text { Dilakukan oleh pejabat publik. } \\
\text { - } \quad \text { Perbuatannya berupa penggelapan, } \\
\text { penyalahgunaan, atau } \\
\text { penyimpangan. } \\
\text { - } \quad \text { Dilakukan terhadap kekayaan, } \\
\text { dana atau sekuritas publik atau } \\
\text { swasta atau barang lain. } \\
\text { - Barang-barang tersebut } \\
\text { dipercayakan kepadanya karena } \\
\text { jabatannya. }\end{array}$ & $\begin{array}{l}\text { Diatur dalam Pasal 8, Pasal 9, dan } \\
\text { Pasal } 10 \text { huruf a, b, dan c UU Nomor } \\
20 \text { Tahun } 2001 . \\
\text { Unsur-unsur delik yang terkandung } \\
\text { dalam pasal-pasal tersebut pada } \\
\text { dasarnya sudah sesuai dengan unsur- } \\
\text { unsur tindak pidana penggelapan, } \\
\text { penyalahgunaan, atau penyimpangan } \\
\text { lain atas kekayaan oleh pejabat } \\
\text { publik, sebagaimana diatur dalam } \\
\text { Pasal } 17 \text { UNCAC, kecuali berkaitan } \\
\text { dengan tindak pidana korupsi yang } \\
\text { dilakukan oleh pihak swasta. }\end{array}$ \\
\hline
\end{tabular}




\begin{tabular}{|c|c|c|c|}
\hline & & $\begin{array}{l}\text { Dilakukan untuk kepentingan } \\
\text { sendiri atau orang lain atau badan } \\
\text { lain. }\end{array}$ & \\
\hline 4. & $\begin{array}{l}\text { Pemanfaatan } \\
\text { pengaruh. }\end{array}$ & $\begin{array}{l}\text { Diatur dalam Pasal } 18 \text { huruf a dan b } \\
\text { UNCAC. } \\
\text { Unsur-unsur tindak pidana Pasal } 18 \\
\text { huruf a UNCAC: } \\
\text { - } \quad \text { Dengan sengaja. } \\
\text { - } \text { Memberikan janji, tawaran atau } \\
\text { pemberian manfaat yang tidak } \\
\text { semestinya. } \\
\text { - } \quad \text { Kepada pejabat publik atau orang } \\
\text { lain. } \\
\text { - Secara langsung atau tidak } \\
\text { langsung. } \\
\text { - Agar pejabat yang bersangkutan } \\
\text { menyalahgunakan pengaruhnya } \\
\text { yang sudah ada. } \\
\text { - Dengan maksud untuk } \\
\text { memperoleh manfaat yang tidak } \\
\text { semestinya untuk kepentingan } \\
\text { penghasut atau untuk orang lain. } \\
\text { Unsur-unsur tindak pidana } \\
\text { Pasal } 18 \text { huruf b UNCAC: } \\
\text { - Dengan sengaja. } \\
\text { - Dilakukan oleh pejabat publik atau } \\
\text { orang lain. } \\
\text { - Secara langsung atau tidak } \\
\text { langsung. } \\
\text { - Meminta atau menerima manfaat } \\
\text { yang tidak semestinya untuk } \\
\text { kepentingan pejabat tersebut atau } \\
\text { orang lain. } \\
\text { - Agar pejabat yang bersangkutan } \\
\text { atau orang lain tersebut } \\
\text { menyalahgunakan pengaruh yang } \\
\text { ada. }\end{array}$ & $\begin{array}{l}\text { Pasal } 18 \text { huruf a UNCAC, tindak } \\
\text { pidana korupsi yang berkaitan dengan } \\
\text { pemanfaatan pengaruh ini erat } \\
\text { kaitannya dengan tindak pidana } \\
\text { korupsi suap menyuap yang diatur } \\
\text { dalam Pasal } 5 \text { ayat (1) huruf a dan b, } \\
\text { Pasal } 5 \text { ayat (2), Pasal } 6 \text { ayat (1) huruf } \\
\text { a dan b, Pasal } 6 \text { ayat (2), Pasal 11, } \\
\text { Pasal } 12 \text { huruf a, b, c, dan d, serta } \\
\text { Pasal } 13 \text { UU Nomor } 20 \text { Tahun } 2001 . \\
\text { Pasal } 18 \text { huruf b UNCAC, identik } \\
\text { dengan tindak pidana korupsi yang } \\
\text { terkait dengan gratifikasi, } \\
\text { sebagaimana diatur dalam Pasal } 12 \text { jo. } \\
\text { Pasal } 12 \text { B UU Nomor } 20 \text { Tahun } 2001 .\end{array}$ \\
\hline 5. & $\begin{array}{l}\text { Penyalahgunaan } \\
\text { fungsi. }\end{array}$ & $\begin{array}{l}\text { Diatur dalam Pasal } 19 \text { UNCAC. } \\
\text { Unsur-unsur tindak pidana Pasal } 19 \\
\text { UNCAC: } \\
\text { - } \quad \text { Dilakukan dengan sengaja. } \\
\text { - } \quad \text { Menyalahgunakan fungsi atau } \\
\text { jabatan. } \\
\text { - } \quad \text { Oleh pejabat publik dalam } \\
\text { pelaksanaan tugasnya. } \\
\text { - } \quad \text { Melaksanakan atau tidak } \\
\text { melaksanakan perbuatan yang } \\
\text { melanggar hukum. } \\
\text { - } \quad \text { Dengan maksud untuk } \\
\text { memperoleh manfaat yang tidak } \\
\text { semestinya untuk dirinya atau } \\
\text { untuk orang lain atau untuk badan } \\
\text { lain. }\end{array}$ & $\begin{array}{l}\text { Pasal } 18 \text { huruf b UNCAC, identik } \\
\text { dengan tindak pidana penggelapan, } \\
\text { penyalahgunaan, atau penyimpangan } \\
\text { lain atas kekayaan oleh pejabat publik } \\
\text { yang diatur dalam Pasal } 8 \text {, Pasal } 9 \text {, } \\
\text { Pasal } 10 \text { huruf a, Pasal } 10 \text { huruf b, dan } \\
\text { Pasal } 10 \text { huruf c UU Nomor } 20 \text { Tahun } \\
2001 .\end{array}$ \\
\hline 6. & $\begin{array}{l}\text { Memperkaya diri } \\
\text { sendiri secara } \\
\text { tidak sah. }\end{array}$ & $\begin{array}{l}\text { Diatur dalam Pasal } 20 \text { UNCAC. } \\
\text { Unsur-unsur tindak pidana Pasal } 20 \\
\text { UNCAC: } \\
\text { - } \quad \text { Dilakukan dengan sengaja. } \\
\text { - } \quad \text { Memperkaya diri sendiri (pejabat } \\
\quad \text { publik). } \\
\text { - } \quad \text { Didapatkan secara tidak wajar. }\end{array}$ & $\begin{array}{l}\text { UU Nomor } 20 \text { Tahun } 2001 \text { telah } \\
\text { memenuhi unsur-unsur tindak pidana } \\
\text { korupsi memperkaya diri sendiri } \\
\text { secara tidak sah yang diatur dalam } \\
\text { UNCAC. }\end{array}$ \\
\hline
\end{tabular}




\begin{tabular}{|c|c|c|c|}
\hline & & $\begin{array}{l}\text { - } \text { Tidak dapat } \\
\text { dipertanggungjawabkan dalam } \\
\text { kaitan dengan penghasilannya } \\
\text { yang sah. }\end{array}$ & \\
\hline 7. & $\begin{array}{l}\text { Penyuapan di } \\
\text { sektor swasta. }\end{array}$ & $\begin{array}{l}\text { Diatur dalam Pasal } 21 \text { huruf a dan } \\
\text { huruf b UNCAC. } \\
\text { Unsur-unsur tindak pidana Pasal } 21 \\
\text { huruf a UNCAC: } \\
\text { - } \quad \text { Dilakukan dengan sengaja. } \\
\text { - } \quad \text { Dalam rangka kegiatan ekonomi, } \\
\text { keuangan, atau perdagangan. } \\
\text { - } \quad \text { Memberikan janji, penawaran, atau } \\
\text { pemberian manfaat yang tidak } \\
\text { semestinya. } \\
\text { - Secara langsung atau tidak } \\
\text { langsung. } \\
\text { - Kepada orang yang memimpin atau } \\
\text { bekerja dalam jabatan apapun atau } \\
\text { orang lain untuk badan sektor } \\
\text { swasta. } \\
\text { - Supaya orang yang bersangkutan } \\
\text { bertindak tidak sesuai dengan } \\
\text { tugasnya. } \\
\text { Unsur-unsur tindak pidana Pasal } 21 \\
\text { huruf b UNCAC: } \\
\text { - Dilakukan dengan sengaja. } \\
\text { - Oleh orang yang memimpin atau } \\
\text { bekerja dalam jabatan apapun atau } \\
\text { orang lain untuk badan sektor } \\
\text { swasta. } \\
\text { - Dalam rangka kegiatan ekonomi, } \\
\text { keuangan, atau perdagangan. } \\
\text { - Meminta atau menerima manfaat } \\
\text { yang tidak semestinya. } \\
\text { - Secara langsung atau tidak } \\
\text { langsung. } \\
\text { - Antuk dirinya atau orang lain. } \\
\text { bertindak tidak sesuai dengan } \\
\text { tugasnya. }\end{array}$ & $\begin{array}{l}\text { Dalam peraturan perundang- } \\
\text { undangan Indonesia, yang diancam } \\
\text { dengan pidana adalah perbuatan } \\
\text { penyuapan atau gratifikasi kepada } \\
\text { pejabat negara. }\end{array}$ \\
\hline 8. & $\begin{array}{l}\text { Penggelapan } \\
\text { kekayaan di } \\
\text { sektor swasta. }\end{array}$ & $\begin{array}{l}\text { Diatur dalam Pasal } 20 \text { UNCAC } \\
\text { Unsur-unsur tindak pidana Pasal } 20 \\
\text { UNCAC: } \\
\text { - } \quad \text { Dilakukan dengan sengaja. } \\
\text { - } \quad \text { Dilakukan oleh orang yang } \\
\text { memimpin atau bekerja dalam } \\
\text { jabatan apapun di badan sektor } \\
\text { swasta. } \\
\text { - Penggelapan terhadap kekayaan, } \\
\text { dana, atau sekuritas swasta atau } \\
\text { barang lain yang berharga. } \\
\text { - Barang-barang tersebut } \\
\text { dipercayakan kepadanya karena } \\
\text { jabatannya. } \\
\text { Dalam rangka kegiatan ekonomi } \\
\text { keuangan atau perdagangan. }\end{array}$ & $\begin{array}{l}\text { Diatur dalam Pasal } 372 \text { jo Pasal } 374 \\
\text { KUHP. Tidak diatur secara tegas } \\
\text { dalam UU Nomor } 20 \text { Tahun } 2001 . \\
\text { Rumusan Pasal } 22 \text { UNCAC, apabila } \\
\text { dikonstruksikan ke dalam hukum } \\
\text { nasional di Indonesia, merupakan } \\
\text { tindak pidana penggelapan pada } \\
\text { umumnya. }\end{array}$ \\
\hline
\end{tabular}

Sumber: Kristian (2015:200-211). 
Tabel 5. Interaksi KPK dengan Warga Negara

\begin{tabular}{|l|c|c|}
\hline & Menindak & Tidak Menindak \\
\hline Korupsi & $U_{O}-U_{D}$ & $U_{O}+U_{R}$ \\
& $B_{E}-C_{P}-C_{S}$ & 0 \\
\hline Tidak korupsi & $U_{R}$ & $U_{R}$ \\
& $B_{R}-C_{P}$ & $B_{R}$ \\
\hline
\end{tabular}

\section{Catatan:}

$\mathrm{U}_{0}=$ Utilitas yang diperoleh dari korupsi.

$U_{D}=$ Disutilitas hukuman (bisa yang sifatnya langsung maupun tidak langsung) dari korupsi.

$U_{R}=$ Utilitas reputasi yang diperoleh warga negara.

$\mathrm{B}_{\mathrm{E}}=$ Manfaat yang diperoleh dari penindakan oleh KPK.

$\mathrm{B}_{\mathrm{R}}=$ Utilitas reputasi dari KPK.

$\mathrm{C}_{\mathrm{P}}=$ Biaya dari operasional (seluruh biaya yang dikeluarkan) KPK.

$\mathrm{Cs}_{\mathrm{s}}$ Biaya untuk memenjarakan koruptor.

Sumber: Handyo (2010:35).

Grafik 1. Kerugian Keuangan Negara Akibat Korupsi

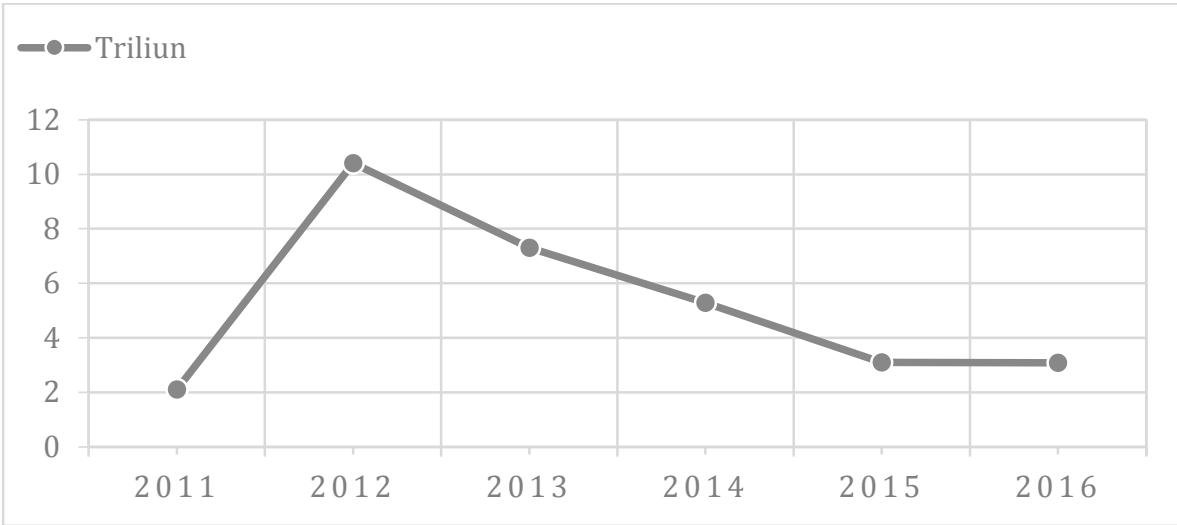

Sumber: Indonesia Corruption Watch

Gambar 3. Tahap Pelacakan Aset I
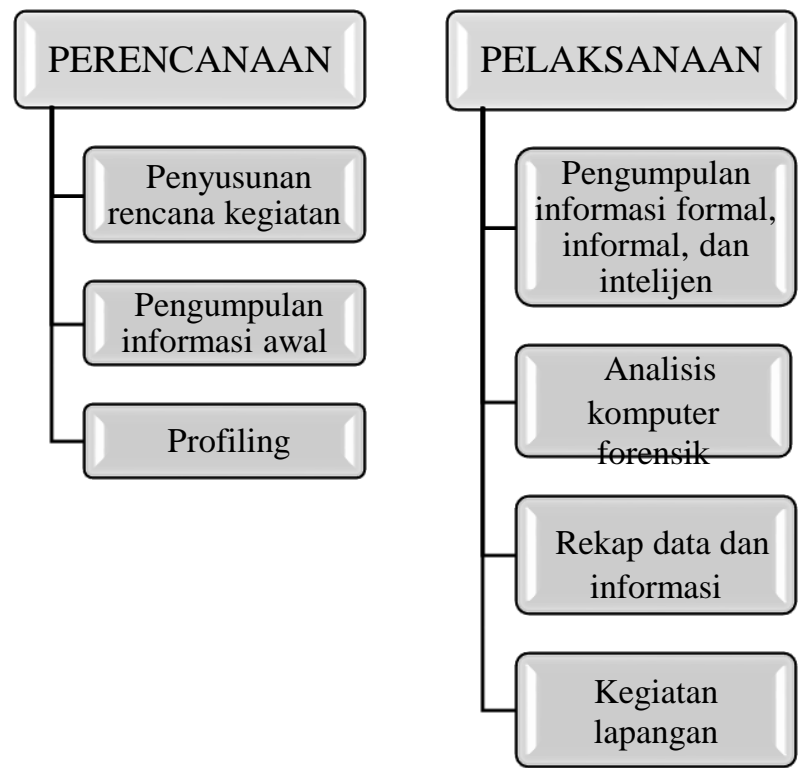

PELAPORAN

Kompilasi data

Analisis nexus

Laporan

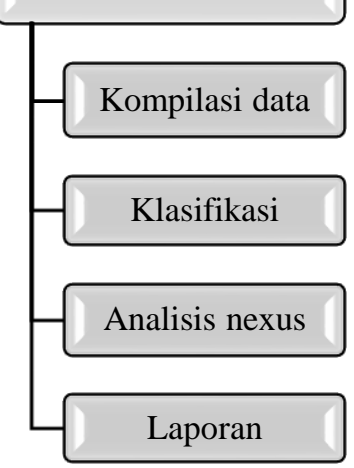

Sumber: Utama (2013: 114).

Gambar 4. Tahap Pelacakan Aset II 
6. Perencanaan

7. Identifikasi/Locating/Profiling

4. Verifikasi (data intelijen)

5. Dokumentasi, pemetaan, dan klasifikasi aset

3. Penelusuran (nexus mapping)

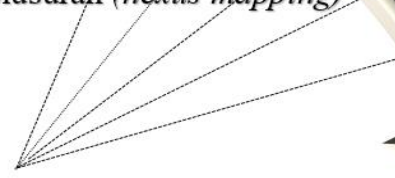

Kerjasama dalam dan luar negeri

2. Analisis

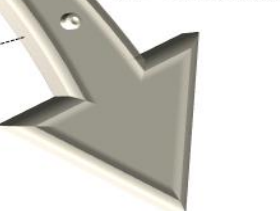

1. Langkah Perampasan

Sumber: Utama (2013:114). 